\title{
Diverse vertebrate assemblage of the Kilmaluag Formation (Bathonian, Middle Jurassic) of Skye, Scotland
}

\begin{tabular}{|c|c|}
\hline Journal: & $\begin{array}{l}\text { Earth and Environmental Science Transactions of the Royal Society of } \\
\text { Edinburgh }\end{array}$ \\
\hline Manuscript ID & TRE-2020-0004.R1 \\
\hline Manuscript Type: & Review Article \\
\hline $\begin{array}{r}\text { Date Submitted by the } \\
\text { Author: }\end{array}$ & $\mathrm{n} / \mathrm{a}$ \\
\hline Complete List of Authors: & $\begin{array}{l}\text { Panciroli, Elsa; University of Oxford, Department of Earth Sciences; } \\
\text { National Museums Scotland, Natural Sciences Department; University of } \\
\text { Edinburgh Department of Geology and of Geophysics, School of } \\
\text { Geosciences } \\
\text { Benson, Roger; University of Oxford, Department of Earth Sciences } \\
\text { Walsh, Stig; National Museums Scotland, Natural Sciences } \\
\text { Butler, Richard; University of Birmingham, School of Geography, Earth } \\
\text { and Environmental Sciences } \\
\text { Andrade Castro, Tiago; University of Oxford } \\
\text { Jones, Marc; University College London, Department of Cell and } \\
\text { Developmental Biology } \\
\text { Evans, Susan; University College London, Department of Cell and } \\
\text { Developmental Biology }\end{array}$ \\
\hline Keywords: & $\begin{array}{l}\text { tetrapods, palaeontology, Great Estuarine Group, mammaliaforms, } \\
\text { salamanders, squamates }\end{array}$ \\
\hline Abstract: & $\begin{array}{l}\text { Abstract: The Kilmaluag Formation on the Isle of Skye, Scotland, } \\
\text { provides one of the richest Mesozoic vertebrate fossil assemblages in the } \\
\text { UK, and is among the richest globally for Middle Jurassic tetrapods. Since } \\
\text { its discovery in } 1971 \text {, this assemblage has predominantly yielded small- } \\
\text { bodied tetrapods, including hyboontiforms, salamanders, choristoderes, } \\
\text { lepidosaurs, turtles, crocodylomorph, pterosaurs, dinosaurs, non- } \\
\text { mammalian cynodonts and mammals, alongside abundant fish and } \\
\text { invertebrates. It is protected as a Site of Special Scientific Interest } \\
\text { (SSSI) and by Nature Conservancy Order (NCO). Unlike } \\
\text { contemporaneous localities from England, this assemblage yields } \\
\text { associated partial skeletons, providing unprecedented new data. We } \\
\text { present a comprehensive updated overview of the Kilmaluag Formation, } \\
\text { including its geology and the fossil collections made to date, with } \\
\text { evidence of several species occurrences presented here for the first time. } \\
\text { We place the vertebrate faunal assemblage in an international context } \\
\text { through comparisons with relevant contemporaneous localities from the } \\
\text { UK, Europe, Asia and the United States. This wealth of material reveals } \\
\text { the Kilmaluag Formation as a vertebrate fossil assemblage of global } \\
\text { significance, both in terms of understanding Middle Jurassic faunal } \\
\text { composition and the completeness of specimens with future implications } \\
\text { for the early evolutionary histories of mammals, squamates and } \\
\text { amphibians. }\end{array}$ \\
\hline
\end{tabular}




\section{SCHOLARONE ${ }^{m}$ \\ Manuscripts}


Diverse vertebrate assemblage of the Kilmaluag Formation (Bathonian, Middle Jurassic) of Skye, Scotland

Elsa Panciroli ${ }^{1,2,3 *}$, Roger B. J. Benson ${ }^{1}$, Stig Walsh ${ }^{2,3}$, Richard J. Butler ${ }^{4}$, Tiago Andrade Castro ${ }^{3}$, Marc E. H. Jones ${ }^{5}$, Susan E. Evans ${ }^{5}$

Running Head: Vertebrate assemblage of Kilmaluag Formation 
26 Abstract: The Kilmaluag Formation on the Isle of Skye, Scotland, provides one of the richest Mesozoic vertebrate fossil assemblages in the UK, and is among the richest globally for Middle Jurassic tetrapods. Since its discovery in 1971, this assemblage has predominantly yielded small-bodied tetrapods, including hybodontiforms, salamanders, choristoderes, lepidosaurs, turtles, crocodylomorph, pterosaurs, dinosaurs, non-mammalian cynodonts and mammals, alongside abundant fish and invertebrates. It is protected as a Site of Special Scientific Interest (SSSI) and by Nature Conservancy Order (NCO). Unlike contemporaneous localities from England, this assemblage yields associated partial skeletons, providing unprecedented new data. We present a comprehensive updated overview of the Kilmaluag Formation, including its geology and the fossil collections made to date, with evidence of several species occurrences presented here for the first time. We

Key Words: tetrapods, palaeontology, Great Estuarine Group, mammaliaforms, 
The Middle Jurassic documents key events in the morphological and taxonomic diversifications of many groups of land vertebrates, including dinosaurs (e.g. Benson et al. 2014; Lee et al. 2014; Rauhut et al. 2016; Benson 2018), mammals (Luo 2007; Close et al. 2016), squamates (e.g. Jones et al. 2013; Burbrink et al. 2019), and amphibians (e.g. Roelants et al. 2007; Gao \& Shubin 2012; Marjanović \& Laurin 2014). Middle Jurassic fossils therefore provide vital information on the origins of groups that played central roles in Mesozoic terrestrial ecosystems, many of which persist to the present. However, terrestrial vertebrates from the Middle Jurassic are rare globally, being known predominantly from China (e.g. Sullivan et al. 2014; Xu et al. 2017), Russia (e.g. Averianov et al. 2005, 2016.), and the UK (e.g. Evans \& Milner 1994; Wills et al. 2019). Within the UK, English Middle Jurassic units yielded the historically earliest discoveries of dinosaurs, pterosaurs, turtles and Mesozoic mammals (Buckland 1824; Blake 1863; Delair \& Sarjeant 2002; Anquetin \& Claude 2008). More recently, extensive screenwashing of sediment bulk samples at localities in Oxfordshire and Gloucestershire has uncovered abundant isolated remains that document a species-rich assemblage of small-bodied vertebrates including amphibians, reptiles and mammals from sites such as Kirtlington (Freeman 1976, 1979; Kermack et al. 1987; Evans 1988, 1990, 1991a, b; 1992, 1994, 1998; Evans et al. 1988, 1990; Evans \& Milner 1994; Gillham 1994; McGowan 1996; Sigogneau-Russell 1998, 2003a; Gardner et al. 2003; Scheyer \& Anquetin 2008). While much attention has been paid to Middle Jurassic outcrops in localities in England, it is only recently that Scottish localities have undergone dedicated palaeontological study, particularly on the Isle of Skye.

The Kilmaluag Formation (Harris \& Hudson 1980) on the Isle of Skye, part of the Great Estuarine Group, is one of the richest fossiliferous formations for vertebrates in Scotland (Whyte \& Ross, 2019). Many of the vertebrates currently known from the Kilmaluag Formation belong to species and genera already reported, but known only from disarticulated remains obtained by bulk sampling of sediments at English Bathonian localities (e.g. Evans et al. 2006; Panciroli et al. 2018a and herein). However, compared to these the Kilmaluag Formation preserves substantially more complete specimens, including partial and near-complete skeletons that represent some of the oldest salamanders, squamates and crown-group mammals. Due to their significance, outcrops are legally protected as Sites of Special Scientific Interest 
(SSSI) and through Scotland's Nature Conservancy Order (NCO) meaning that fossils can only be collected for scientific purposes through permits from Scottish Natural Heritage (SNH).

The first fossils from the 'vertebrate beds' of the Kilmaluag Formation were discovered in 1971 by Michael Waldman, a teacher at Stowe School (Waldman \& Savage 1972). Waldman and his colleague and mentor, Robert Savage (University of Bristol), undertook seven field trips between 1971 and 1982. Further fieldwork was undertaken in the early 2000s by a team from the Natural History Museum in London, NMS, University College London, and the University of Oxford, under leadership of Susan Evans and Paul Barrett. Since 2010 fieldwork has continued, led by Roger Benson (University of Oxford), Stig Walsh (National Museums Scotland), Richard Butler (University of Birmingham), and Elsa Panciroli (University of Oxford), along with other participants (see Acknowledgements). A wealth of material collected by multiple expeditions has revealed the Kilmaluag Formation as one of the richest vertebrate fossil localities in the UK, and of global significance both in terms of faunal composition, and the completeness of specimens.

An overview of the fossil finds from the Kilmaluag Formation was last provided in 2006 (Evans et al. 2006). New discoveries since then have considerably expanded our knowledge of this assemblage and its global importance as a site for Middle Jurassic vertebrates. Here we provide an up-to-date overview of the geology and collections, and discuss potential collection biases caused by the hard-weathering nature and poor reaction to acid of the limestone, which makes it unsuitable for bulk processing. We make comparisons between the Kilmaluag Formation faunal assemblage - particularly mammals, salamanders and squamates_and relevant contemporaneous localities from the UK, Europe, Asia and the United States. These comparisons provide international context for the Kilmaluag Formation assemblage, and provide evidence regarding proposed global distribution patterns and macroevolutionary trends in various mammal groups and their close relatives.

Institutional Abbreviations-NMS, National Museums Scotland, Edinburgh; NHMUK, Natural History Museum, London; CAMSM, Sedgewick Museum of Earth Sciences, University of Cambridge. 


\section{Geological Overview}

The Kilmaluag Formation (Harris \& Hudson 1980) is part of the Great Estuarine Group (formerly Great Estuarine Series [Judd 1878, p722]), a series of near-shore shallow marine, varied salinity lagoon and freshwater lagoon sediments of Bathonian age (Harris \& Hudson 1980; Andrews 1985; Barron et al. 2012) (Fig. 1). The Great Estuarine Group comprises the Middle Jurassic portion of the Sea of Hebrides Basin and Inner Hebrides Basin: tectonically bound basins with sedimentology that reflects fluctuating sea-levels caused by subsidence and uplift (Morton 1987; Mellere \& Steel 1996; Hesselbo \& Coe 2000). These Mesozoic sediments are overlain disconformably by Tertiary basalt (Harris \& Hudson 1980).

The Kilmaluag Formation crops out on the Scottish Inner Hebridean islands of Eigg, Skye and Muck, and is approximately $25 \mathrm{~m}$ in thickness at the most complete section on the Strathaird Peninsula on Skye (Harris \& Hudson 1980; Morton \& Hudson 1995) (Figs 1-2). It was formerly known as the Ostracod Limestone, and the base of the formation is defined by the occurrence of ostracod-bearing calcareous mudstones and marls/fissile mudstones (Anderson \& Dunham 1966; Harris \& Hudson 1980; Andrews 1985; Barron et al. 2012). It is named for the village of Kilmaluag on the Trotternish Peninsula of Skye, where the type section crops out along the shore of Kilmaluag Bay (Harris \& Hudson 1980). Despite being less extensive than exposures on the Strathaird Peninsula in southern Skye, Kilmaluag was chosen as the locality of the type section as it is accessible and fossiliferous, and the base of the formation can be easily defined to within 3 m (Harris \& Hudson 1980).

The age of the Kilmaluag Formation correlates with the Retrocostatum Zone, and is late Bathonian in age (Barron et al. 2012), just over 166.1 Ma (Cohen et al. 2019). The similarities in vertebrate faunal composition with that from the Kirtlington Cement Quarry (Forest Marble Formation, see below) in England also support a late Bathonian age. Unlike other formations within the Great Estuarine Group, the Kilmaluag Formation includes predominantly low-salinity and freshwater facies, especially on the Strathaird Peninsula, as demonstrated by the presence of freshwater ostracods (Darwinula and Theriosynoecum: Wakefield 1995), shallow 
freshwater to oligohaline conchostracans (such as Anthronesteria and Pseudograpta: Chen \& Hudson 1991) and freshwater gastropods (Viviparus: Andrews 1985; Morton \& Hudson 1995; Barron et al. 2012) (Fig. 3).

The Kilmaluag Formation can be divided into two distinct facies: predominantly siliciclastic facies in northern Skye, including sandstones; and predominantly argillaceous (muddy) limestone facies found on the Strathaird Peninsula in southern Skye, and also in small outcrops on Eigg and Muck, which do not include sandstones (Andrews 1985). Palaeoenvironmental reconstructions of the siliciclastic facies suggest a low-salinity environment of closed lagoons or marginal coastal lakes, fed by small rivers which carried in siliciclastic sediments and plant material (Andrews 1985). Multiple layers of desiccation cracks, and reworked desiccation breccias infilling mudcracks, suggest periodic drying out followed by wetter periods of lagoon expansion. There are also rippled sandsheets in some beds, with tuningfork bifurcations indicative of wave generation (Andrews 1985).

The argillaceous limestone facies were depositional rather than diagenetic in origin and contain up to $44 \%$ acid-insoluble residues (Andrews 1985). These beds are locally altered by metamorphism resulting from Palaeogene igneous intrusions (Hesselbo \& Coe 2000). The mud-dominated lower beds, which alternate between muds with high clay content, and muddy-carbonates with lower clay content represent a low-salinity to freshwater lagoon environment, which evaporated in drier seasons and expanded in wetter seasons (Andrews 1985). This environmental interpretation is supported by alternating clay-rich muds, and muddy carbonates that are dominated by disarticulated ostracod bioclasts and structureless micrite introclasts (Andrews 1985). Infrequent dolomites probably represent the dolomitisation of precursor carbonates during extreme periods of desiccation (Andrews 1985:1128). This would have exposed mudflats, forming desiccation cracks and flat-pebble conglomerates. The argillaceous facies were fed by meteoric waters, unlike the clastic facies in the north. This interpretation of a low-salinity closed lagoon environment is supported by a palynoflora that includes Tasminites and Botryoccus (Riding et al. 1991). 
Andrews (1985) informally divided the Kilmaluag Formation into a series of numbered horizons, with horizons 9 and 10, near the middle of the sequence, also known as the 'Vertebrate Beds'. These beds are highly fossiliferous, located on the Strathaird Peninsula, and are thought to represent a predominantly wet climatic phase. These beds alternate between muddy carbonates, hard blue-grey limestones, micrites, wackestones and breccia conglomerates, and appear to be predominantly freshwater (Andrews 1985). The lowest MgO content is found in these beds, and in some there is smooth millimetre-scale lamination, and some stromatolitic domed laminations, which suggests a shallow sublittoral depositional environment. Vertebrate fossil remains in the Kilmaluag Formation are black in colour, and are scattered throughout.

Breccia beds that overlie the vertebrate beds also yield body and trace fossil material (see below) (Andrews 1985; Marshall 2003) (Fig. 2). The breccia beds comprise three dolomitic, gradationally bound beds combined into one bedset (Marshall 2003). Each bed consists of silty micrite which becomes brecciated upwards across a desiccation cracked horizon. The brecciation and mudcracks are inferred to result from prolonged subaerial exposure and desiccation (Marshall 2003). This evidence, coupled with the lack of fossilised vegetation, suggests these beds represent a barren or sparsely vegetated supralittoral lagoon margin (Marshall 2003).

\section{Fossil Flora and Fauna of the Kilmaluag Formation}

\subsection{Flora}

No in-depth palaeobotanical studies have been made of the plant fossils of the Great Estuarine Group. Floral remains mostly comprise poorly preserved fragments, and only rare small broken pieces of bark and stem occur in the Kilmaluag Formation (EP, pers. obs.). A single palynological study included data from the Kilmaluag Formation in the Trotternish Peninsula of northern Skye as part of a wider analysis of the Jurassic rocks of the Hebrides Basins (Riding et al. 1991). They took 16 samples from the Isle of Skye, 12 of them from the type section at Port Gobhlaig in Kilmaluag Bay and four at Prince Charles' Point. These samples indicated low palynological 
diversity dominated by gymnosperm pollen (up to $87 \%$ ), with $<24 \%$ pteridophyte spores (Riding et al. 1991:p143).

\subsection{Invertebrate fossils}

The most abundant invertebrate fossils of the Kilmaluag Formation are arthropods, notably ostracods, principally Darwinula and Theriosynoecum (Wakefield 1995), and the conchostracans Anthronesteria and Pseudograpta (Chen \& Hudson 1991). There are also molluscs such as the gastropod Viviparus and the bivalve Unio (Harris \& Hudson 1980; Andrews 1985). Trace-fossil burrows attributed to larger decapods are also preserved in the vertebrate beds and breccia beds on the Strathaird Peninsula of southern Skye and are interpreted as dwelling burrows for crabs or shrimps (Marshall 2003).

Only a handful of other invertebrate fossils are known from the Kilmaluag Formation. Insect-bearing strata were discovered by EP in 2017 at an outcrop of Kilmaluag Formation at Lub Score on the Trotternish Peninsula. Subsequently, multiple specimens have been collected and await description (under study by A. Ross). These mainly comprise beetle wing cases that cannot be assigned above ordinal level, but continued collection should yield sufficient data to give some indication of insect faunal diversity in the future.

\subsection{Chondrichthyes and Osteichthyes}

Three chondrichthyan and two osteichthyan taxa have been described from the Kilmaluag Formation to date. The chondrichthyans are hybdont sharks: Acrodus, Hybodus and an indeterminate hybodont (Rees \& Underwood 2006; Evans et al. 2006). The Acrodus specimens represent new species, and comprise the only nonmarine Jurassic occurrences in Europe, and some of the youngest occurrences of this genus known (Rees \& Underwood 2006) (Fig. 3). Pycnodont scales are visible at outcrop (EP and RBJB, pers. obs.). The semionotiform Lepidotes and an unidentified sarcopterygian (?coelacanth) have previously been recovered (Evans et al. 2006), and some partial mandibles belonging to amiiforms were collected recently, but not yet described. All of these are known from isolated scales, teeth and/or tooth fragments. In the last decade of fieldwork more fossil fish have been recovered (e.g. 
250

251

252

253

254

255

256

257

258

259

260

261

262

263

264

265

266

267

268

269

270

271

272

273

274

275

276

277

278

279

280

281

282

Fig. 3D), including partial associated skeletons that currently await preparation and study.

\subsection{Lissamphibia}

Two species of salamander and one albanerpetontid are known from the Kilmaluag Formation (Evans \& Waldman 1996; Evans et al. 2006). The salamanders, Marmorerpeton and (the informally named) 'Kirtlington salamander A', were both originally reported on the basis of isolated elements obtained by screenwashing from the Middle Jurassic Forest Marble Formation of Kirtlington, England (Evans et al. 1988; Evans \& Milner, 1994; Evans et al. 2006). There is currently no evidence of frogs or caecilians from Skye, although frogs have been described from the Kirtlington microvertebrate assemblage (Evans et al., 1990).

Marmorerpeton is a relatively large, paedomorphic, aquatic salamander (Evans et al. 1988; Evans \& Milner 1994; Evans \& Waldman 1996). Most material is estimated to come from animals $25-30 \mathrm{~cm}$ long (Evans et al. 1988). One partial skeleton was collected from Skye by Waldman and Savage (reported in Evans \& Waldman 1996), but has not yet been described. Recent fieldwork has recovered a second part of the same skeleton, as well as several addition partial skeletons. Collectively these specimens include most of the skull and postcrania and they are currently under study (Jones et al. 2018a).

Accessioned material of M. kermacki includes an association of vertebrae, limb and skull elements (NMS G.1992.47.9), two fused caudal vertebrae (NMS G.1992.47.12), multiple isolated vertebrae (NMS G.1992.47.25, NMS G.1992.47.26 and NMS G.1992.47.27), and a partial ilium (NMS G.1992.47.15; Evans \& Waldman 1996:fig 1b).

The strongly sculptured skull bones, proportions of the atlas, absence of spinal nerve foramina in the atlas (Evans et al. 1988), and features of the ilium suggest that Marmorerpeton may be an early karaurid, a group of stem salamanders that are known from the Middle Jurassic to Early Cretaceous of Kyrgyzstan, Kazakhstan, and Russia (Ivakhnenko 1978; Nesov 1988; Nesov et al. 1996; Skutschas \& Martin 2011; 
Skutschas \& Krasnolutskii 2011; Skutschas 2013; 2014a, b; Skutschas et al. 2018). Whether this group is monophyletic or paraphyletic (sharing several plesiomorphic characters) remains to be established. The proportions of two undescribed atlantes among the Scottish material most closely resemble those of $M$. kermacki, one of the two species named from Kirtlington (Evans et al. 1988).

A second salamander, referred to informally as 'Kirtlington Salamander A' (Evans \& Milner 1994), is also present at Skye (Evans \& Waldman 1996; Evans et al. 2006) and is relatively common there, based on recently collected material (Fig. 4H-K). Salamander A was probably smaller than Marmorerpeton (Evans \& Milner 1994) but was also likely aquatic. Multiple isolated elements of 'Kirtlington Salamander A' from Skye—mostly vertebrae-are accessioned at NMS, including NMS G.1992.47.14. To date the only published image of 'Kirtlington Salamander A' is a dorsal vertebra in lateral view (Evans \& Waldman 1996:fig 1a). However, associated skeletons that include skull roof and braincase elements have been found more recently and are currently under study (Jones et al. 2018a).

Features of the atlas and vertebrae (e.g. absence of spinal nerve foramina, no interglenoid tubercle) suggest that 'Kirtlington salamander A' is a stem salamander (Jones et al. 2018a). It is easily distinguished from Marmorerpeton due to its shorter dorsal vertebrae that have shallow rib bearers, less textured skull bones, and wider notochordal canals.

Albanerpetontids are represented by just one specimen, a pair of articulated premaxillae, collected in 2014 (NMS G.2019.34.6) (Fig. 4A-B, D). The specimen shows many similarities with Anoulerpeton priscus, previously known only from the microvertebrate assemblage at Kirtlington (Gardner et al. 2003).

\subsection{Lepidosauromorpha}

The Kilmaluag Formation has yielded a diversity of lepidosauromorphs (Waldman \& Evans 1994; Evans \& Waldman 1996; Evans et al. 2006; work in progress), including some of the earliest crown squamates, as well as more basal taxa. 
Marmoretta sp. is the most abundant small reptile in the Kilmaluag assemblage, represented by multiple dentaries and maxillae including CAMSM $\times 991$, as well as the partial skeleton NMS G.1992.47.1 (Waldman \& Evans 1994:fig 6-9), and the maxillae NMS G.1992.47.4 (Fig. 5A-C) and NMS G.1992.47.5 (Waldman \& Evans 1994:fig 5). Marmoretta was originally described from the microvertebrate assemblage at Kirtlington (Evans 1991a) and other English Bathonian sites (Evans 1992; Evans \& Milner 1994) and is also known from the Late Jurassic of Portugal (Evans 1991a). The partial skeleton NMS G.1992.47.1 remains the most complete specimen of Marmoretta (Evans 1991a; Evans \& Waldman 1994). Only the skull and limited aspects of postcranial morphology have been described so far (Waldman \& Evans 1994:figs 6-8). However, microCT scans indicate a more substantially complete and 3D preserved skeleton largely covered by matrix that is currently under study.

Recent fieldwork has substantially extended the number of known lepidosaur fossils from the Kilmaluag Formation, including the collection of more than 20 isolated toothbearing elements and several partial or near-complete skeletons. To date these new specimens represent squamates and stem-group lepidosaurs. No rhynchocephalians are currently known. Rhynchocephalians are also rare in other Middle Jurassic assemblages in the UK: only three incomplete bones were reported previously from Kirtlington Cement Quarry (Evans 1992; Evans \& Milner 1994) despite bulk sampling of large quantities of sediment (Ward 1984) and abundant remains of other lepidosaurs (e.g. Evans 1988; Evans \& Milner 1994).

Two partial dentaries with subpleurodont dental implantation show notable differences from each other and from dentaries of Marmoretta (NMS G.1992.47.1 and referred specimens from Kirtlington; Evans 1991a; Waldman and Evans 1994). Both might represent distinct lepidosauromorph species. Lepidosauromorph 'species A', NMS G.2019.34.9 (Fig. 5D-E), differs from Marmoretta in having a dentary that is dorsoventrally expanded towards the symphysis, giving the ventral margin a strongly curved outline. Seen in lingual view, the anterior end of the bone has an unusual morphology. The rounded subdental shelf develops a sharp-edged and facetted flange, presumably for articulation with a large splenial. Below this, the expanded ventral margin is also facetted. 
Lepidosauromorph 'species B', NMS G.2019.34.13, is a partial left dentary recovered in 2015 (Fig. 5F-I) with subpleurodont dental implantation may represent a distinct taxon from Marmoretta. It differs from Marmoretta in possessing conical teeth with apices that are not recurved (those of Marmoretta are curved apicoposteriorly). Some teeth have mesiodistally wide bases and others have mesiodistally narrow bases, whereas the teeth of Marmoretta vary only gradually (mesial teeth have narrow bases and are smaller). Neither specimen is currently considered sufficient as the basis for a new species but nevertheless these specimens show a potentially larger and as yet unappreciated diversity of primitive lepidosauromorphs in the assemblage.

Several squamates or stem-squamates have been reported so far, based predominantly on tooth bearing elements (dentaries and maxillae), as well as isolated vertebrae. Waldman \& Evans (1994) described two isolated dentaries - the almost complete right and a partial left dentary of what they referred to Paramacellodus sp. (NMS G.1992.47.2; NMS G.1992.47.3; Waldman \& Evans 1994:fig 4) based on overall similarities of the jaw shape (e.g. orientation of the Meckelian canal, elongated lateral depression) and tooth morphology (chisel-shaped striated tooth tips, posteriorly directed). A similar left dentary was collected in 2016 (NMS G.2019.34.11) (Fig. 6C-E). Furthermore, micro-CT scans of NMS G.1992.47.2 reveal a right frontal, left pterygoid with a single pterygoid tooth row, and abraded right humerus within the matrix. These show additional paramacellodid-like features including paired frontals of roughly equal anterior and posterior width with an interdigitating median suture (Evans \& Chure 1998). The frontals differ from those of Paramacellodus in having a more complex median interdigitation, in lacking any obvious interdigitation of the frontoparietal suture, and in having a deeper anteroventral descending lamina. However, the absence of osteoderms associated with any of these specimens, or even as isolated elements in the matrix, suggests that these specimens do not belong to Paramacellodus and they are referred here to Squamata cf. Paramacellodidae indet.

An assemblage of tiny skull bones including a right dentary, partial right maxilla, and a partial right prefrontal collected in 2015 is referred to Balnealacerta silvestris (NMS 
G.2019.34.3) (Fig. 7A-G). This identification is based on detailed similarities of the anterior part of the dentary, including the anterodorsal angulation of the Meckelian groove at the symphysis and the presence of a long ventrolateral muscle scar. Balnealacerta silvestris was originally reported from Kirtlington and referred to Paramacellodidae (Evans 1998) based on similarities of the dentary and tooth morphology to those of other paramacellodids. However, no trace of the characteristic oblong osteoderms characteristic of paramacellodids has been found either at Kirtlington or in the Skye material, raising doubts regarding its paramacellodid affinity.

Evans \& Waldman (1996, Fig. 4) reported a dentary and parts of other bones scattered on a slab as Scincomorpha indet. (NMS G.1992.47.10). Here we note strong similarity of that specimen to the holotype of Bellairsia gracilis, (NHMUK PV R12678) reported previously from Kirtlington as of the most abundant reptiles in that assemblage (Evans 1998). These specimens share a gracile jaw morphology (slender and parallel-sided rather than 'boat-shaped), open Meckelian groove, and small, lingually striated teeth. Therefore, we refer NMS G.1992.47.10 to Bellairsia sp. We also report an incomplete left dentary preserved in two parts (the symphysis and a central portion; NMS G.2019.34.1) (Fig. 7H-M) that shares the slender teeth, relatively simple tooth tips, low subdental shelf and pattern of prearticular and angular faceting with the holotype of Bellairsia from Kirtlington (NHMUK PV R12678). Finally, a near-complete, articulated skeleton, probably referable to Bellairsia, that was collected in 2016 is currently under study.

Waldman \& Evans (1996) reported multiple vertebrae from the Kilmaluag Formation as being similar to subadult specimens of the squamate Parviraptor from the microvertebrate assemblage of Kirtlington. The presence of Parviraptor-like squamates in the Kilmaluag Formation has been confirmed by the discovery of further material, which is currently under study.

Referrals of individual vertebrae to Parviraptor are complicated. Parviraptor estesi was originally reported from the Early Cretaceous Purbeck Group of the UK (Evans 1994) and referred to Anguimorpha. Additional species of Parviraptor were subsequently erected based on specimens from the Late Jurassic of North America 
418 (Evans 1996; Evans \& Chure 1998) and Portugal (Evans 1994, 1996), and specimens from the microvertebrate assemblage from the Middle Jurassic of Kirtlington were referred to Parviraptor cf. $P$. estesi by Evans (1994). Recently, many of these specimens were referred to new genera or new genera and species, and this group was attributed to stem-group snakes (Caldwell et al. 2015). Here we simply confirm the present of Parviraptor-like specimens from the Kilmaluag Formation of Skye that are under ongoing study.

A new squamate dentary, NMS G.1992.47.125, with weakly tricuspid teeth (Fig. 6AB) was also found during fieldwork in 2004 and is distinct from other specimens both from Skye and from Kirtlington Cement Quarry (Evans et al. 2006). Among the asyet unidentified squamate material is a gekkotan-like vertebra (G.1992.47.13: Evans et al. 2006), and multiple fragmentary specimens that cannot yet be identified.

\subsection{Testudinata}

Turtle fossils are common in the Kilmaluag Formation on the Strathaird Peninsula, mostly comprising broken non-associated portions of turtle carapace and plastron (e.g. NMS G.1992.47.25; Evans \& Waldman 1996; Evans et al. 2006), but also some significant associated material (Anquetin et al. 2009) (Fig. 8A). A new genus and species of stem turtle, Eileanchelys waldmani (Anquetin et al. 2009; Anquetin 2010), was named from material recovered during field work in 2004 . This material included the holotype partial skull, NMS G 2004.31.15 and the paratypes NMS G 2004.31.16a-f, in total comprising at least three associated partial skeletons on the same limestone block. The paratype material includes postcrania and almost complete carapaces. Eileanchelys waldmani represents one of the earliest recorded aquatic turtles, and one of the few known from the Middle Jurassic. Its mixture of plesiomorphic and derived characters make it a key taxon in tracking the morphological evolution of the vomer and basicranium from basalmost to crowngroup turtles (Anquetin et al. 2009).

\subsection{Choristodera}

The choristodere Cteniogenys is represented by a partial skull from the Kilmaluag Formation, NMS G.1992.47.11 (Evans \& Waldman 1996:fig 3). Cteniogenys 
antiquus was originally named on the basis of jaw elements from the Late Jurassic Morrison Formation of North America (Gilmore 1928) and further specimens of Cteniogenys were reported from the Late Jurassic of Portugal (Seiffert 1970; Cteniogenys reedi). Gilmore and Seiffert interpreted Cteniogenys as a stemsquamate, but analysis of abundant elements from the Middle Jurassic microvertebrate assemblage of Kirtlington showed that Cteniogenys was an early choristodere (Evans 1989, 1991b). Some specimens of Cteniogenys sp. from the Kilmaluag assemblage are more complete and include associated sets of elements (e.g. Evans \& Waldman 1996:fig 3). A tiny broken skull of Cteniogenys, NMS G.2019.34.4, from the Kilmaluag assemblage is currently under study.

\subsection{Reptilia indet.}

Four specimens of uncertain affinity are here referred to as Reptilia 'species A' (NMS G.1992.17.124 and NMS G.1992.17.126), Reptilia 'species B' (NMS G.2019.34.7) and Reptilia 'species C' (NMS G.2019.34.12). These specimens all likely constitute new taxa, but lack synapomorphies that would allow them to referred to any of the other clades mentioned herein, and are insufficiently well-known to provide a basis for new species names.

Reptilia 'species A' is known from two near-complete dentaries with subthecodont dental implantation and conical teeth (NMS G.1992.47.124 and NMS G.1992.47.126). These dentaries are unusual in that they become dorsoventrally narrow in their anterior one third, even allowing for breakage. Although the dentition is reminiscent of that of Cteniogenys in general appearance, these dentaries lack the double rows of grooved labial neurovascular foramina that characterise the jaws of choristoderes.

Reptilia 'species B' is known from a single left dentary (NMS G.2019.34.7). It is shorter than the dentary of Reptile A, or Cteniogenys, and lacks the marked anterior taper of Reptile A and the double row of neurovascular foramina seen in Cteniogenys. 
483 Reptilia 'species C' is based on a remarkably small tooth-bearing portion of dentary,

484 NMS G.2019.34.12 which was discovered in 2016. It has subthecodont dental

485

486

487

488

489

490

491

492

493

494

495

496

497

498

499

500

501

502

503

504

505

506

507

508

509

510

511

512

513

514

515 implantation and differs from Cteniogenys in possessing slightly recurved teeth and lacking the characteristic labial foramina.

\subsection{Crocodylomorpha}

The first crocodylomorph material described from the Kilmaluag Formation comprised an indeterminate partial postcranial skeleton, NMS G.1992.47.6, belonging to an animal approximately 1 metre in length (Waldman \& Evans 1996) (Fig. 8B). This includes elements of the right hind limb and scapula, fragments of rib, three dorsal vertebrae and multiple osteoderms. The authors suggested the small size and postcranial morphology of the material was not suggestive of a goniopholid, although goniopholid teeth are common in other Bathonian sites. A crocodylomorph left pubis (NMS G.1992.47.51), some osteoderms (NHMUK PV R36713), and a single goniopholid tooth (NHMUK PV R36713) were described by Wills et al. (2014) from the Kilmaluag Formation of the Strathaird Peninsula and comprised the first figured crocodylomorph material from that region. The pubis was collected in 1992, and the osteoderms and tooth in 2006. These specimens are attributed to indeterminate goniopholid neosuchians. Isolated crocodylomorph material is also included in faunal lists (Evans \& Milner 1994; Evans et al. 2006), but not described or figured. Evans et al. (2006) mention atoposaurid material, although it is not figured or described. Atoposaurid teeth are regularly visible at outcrop.

\subsection{Pterosauria}

Two associated skeletons of pterosaurs are currently under study from the Kilmaluag Formation: one that represents a monofenestratan pterosaur, NHMUK PV R37110 (Martin-Silverstone et al. 2019); and one as yet unprepared specimen that appears to be non-pterodactyloid (Fig. 8D). Several teeth thought to represent pterosaurs have also been identified (Evans et al. 2006).

\subsection{Dinosauria}

Although dinosaur body and ichnofossils are known from other parts of the Great Estuarine Group (see Clark [2018] for overview), very little dinosaur material has 
been recovered from the Kilmaluag Formation to date. However, the scant material that does exist currently represents the geologically youngest non-avian dinosaur material in Scotland. The trackways of small bipedal tridactyl dinosaurs at Lub Score on the Trotternish Peninsula (Clark et al. 2005) possibly represent adult and juvenile theropods, most likely the same ichnospecies. They were found in two distinct stratigraphic layers: a silty mudstone, and a sandstone containing darker organic layers. Both are suggested to represent freshwater depositional settings, but exact correlation with the stratigraphy in other parts of the Isle of Skye has proven problematic (Clark et al. 2005).

The only dinosaur body fossil remains reported so far from the Kilmaluag Formation are an isolated sauropod tooth, NMS G 2004.31.1 (Fig. 8C), which represents the first dinosaur tooth described from Scotland (Barrett 2006), an incomplete taxonomically indeterminate femur, NMS G.2003.31.20, and theropod tooth, NMS G.1992.47.50, all from the Strathaird Peninsula (Wills et al. 2014). The sauropod tooth comprises a complete crown with partial root, with morphology suggesting it is referable to either a basal eusauropod or basal titanosauriform (Barrett 2006). Further material that may be attributable to dinosaurs is currently being prepared for further study.

\subsection{Mammaliamorpha}

The first non-mammalian cynodont from Scotland was found in the Kilmaluag Formation on the Isle of Skye. It was placed in a new species, Stereognathus 'hebridicus', based on four isolated postcanines (holotype BRSUG 20572; paratypes BRSUG 20573, BRSUG 20574, BRSUG 20575), which appeared to be larger than the English S. ooliticus (Waldman \& Savage 1972). Following detailed morphological comparison of specimens assigned to these two species, with the addition of betterpreserved specimens recovered from the Kilmaluag Formation since the 1970s, these species were synonymised under S. ooliticus (Panciroli et al. 2017a) (Fig. 9AB). S. ooliticus in the UK is almost entirely represented by isolated postcanine teeth, with only two partial maxillae: one edentulous, and the other the holotype, BGS GSM113834, consisting of three postcanines in a maxillary fragment. Isolated limb bones from English Jurassic sites such as Kirtlington Cement Quarry (Forest Marble 
549 Formation) have been assigned to Tritylodontidae (Simpson 1928; Kühne 1956), but 550 their identification as Stereognathus is unconfirmed.

551

The first Mesozoic mammaliaform from Scotland came from the Kilmaluag

Formation: the new genus and species of docodont, Borealestes serendipitus

(Waldman \& Savage 1972). Only one specimen of Borealestes was described, the holotype partial dentary BRSUG 20570 (Fig. 9K), which bears three premolars and six molars (Waldman \& Savage 1972). Further specimens (BRSUG 20571 and BRSUG 29007) were collected subsequently during fieldwork in the 1970s and 1980s, but were not described until recently (Panciroli et al. 2018c, 2019). Borealestes was the third docodont genus to be named (after Docodon victor [Marsh 1880] and Peraiocynodon inexpectatus [Simpson 1928] —although the latter was synonymised with Docodon [Butler 1939], only to be resurrected again later [Sigogneau-Russell 2003a]), and the original diagnosis was not comprehensive. Later authors expanded the diagnosis of $B$. serendipitus for upper and lower molars, and added a second species (B. mussettae) based on individual molars found at Kirtlington Cement Quarry (Sigogneau-Russell 2003a; Luo \& Martin 2007), although their attribution to Borealestes is now being re-evaluated (Panciroi et al. in review).

Multiple dentaries of Borealestes are now known from the Kilmaluag Formation, including an almost complete dentary NMS G.1992.47.121.3 (Panciroli et al. 2019) (Fig. 9L-M), which belongs to the associated skeleton NMS G.1992.47.121.1 (Panciroli et al. in review). Most of these specimens were collected in the 1970s, but a new, almost complete dentary was recovered during fieldwork in 2016 (NMS G.2018.27.1), and another associated skeleton was recovered in 2018 belonging to a new species of Borealestes (Panciroli et al., in review). Together these specimens have permitted the clarification of the diagnosis of Borealestes (Panciroli et al. 2019; manuscript in review), and they include some of the most complete crania and postcrania for any Mesozoic mammaliaform from the British Isles.

Further mammaliaform material was recovered and recorded in published faunal lists 
confirmed as belonging to a docodont (NMS G.1992.47.122.1) and is currently under study by EP.

Recent fieldwork recovered another mammaliaform dentary, belonging to the morganucodontan Wareolestes rex (Panciroli et al. 2017b) (Fig. 9C-E). The first crown-group mammal from the Kilmaluag Formation, the cladotherian Palaeoxonodon ooliticus was also recently described (Close et al. 2016; Panciroli et al. 2018b) (Fig. 9d). Both taxa were known previously from isolated teeth from the Forest Marble Formation (Freeman 1976, 1979; Butler \& Sigogneau-Russell 2016), but the Scottish specimens are more complete, consisting of teeth set within nearcomplete dentaries.

The specimen of Wareolestes rex, NMS G.2016.34.1, is the most complete for this taxon, consisting of two erupted molars and two unerupted premolars in a partial dentary (Panciroli et al. 2017b). The in situ molars settle disagreement over the orientation within the tooth row of previously recovered isolated molars from the Forest Marble Formation (thought to be upper molars, but now identified as lowers) (Freeman 1979; Hahn et al. 1991; Butler \& Sigogneau-Russell 2016; Panciroli et al. 2017b). Erupting teeth present below the alveolar margin of the dentary suggest a derived tooth replacement pattern for this early-diverging mammaliaform.

\section{The nearly complete dentary of Palaeoxonodon ooliticus, NMS G. 2015.17.10,} includes an incisor, canine, three premolars and five molar teeth in situ within the dentary (Close et al. 2016) (Fig. 9F-H). A second portion of dentary, NMS G.2017.37.1, includes a portion of the coronoid base that is missing from NMS G. 2015.17.10 (Fig. 9G-H), and provides additional information for phylogenetic analyses, further supporting this genus as a stem cladotherian closely related to Amphitherium (Panciroli et al. 2018b). The morphological variation along the tooth row in NMS G. 2015.17.10 indicates that the morphologies of previously erected cladotherian taxa, Palaeoxonodon ooliticus, P. leesi, P. freemani, and Kennetheridium leesi (Sigogneau-Russell 2003b), all fall within the range of variation observed in $P$. ooliticus. They are therefore considered to be junior synonyms of $P$. ooliticus (Close et al. 2016). Postcranial material from Palaeoxonodon is currently under study by EP. 
617 Postcrania and crania belonging to Phascolotherium have also been recovered (Fig. $9 \mathrm{~N}$ ) and are currently under study by EP.

\section{Comparisons to Vertebrate Faunas from Other Sites}

621 The vertebrate fauna of the Kilmaluag Formation represents one of the richest 622 Mesozoic vertebrate-bearing sites in the British Isles. Nevertheless, the vertebrate 623 faunal list (Table 2) essentially represents a subset of the species found in the Forest Marble Formation of England (see Supplementary material), with many of the same taxa represented. The Kilmaluag Formation vertebrate fauna also resembles those from other Middle Jurassic localities such as the Anoual Formation (Guelb el Ahmar fauna) in Morocco and Itat Formation in Russia, with broad compositional similarities based on the shared presence of higher taxa. The Kilmaluag assemblage shares fewer taxa in common with those represented in Late Jurassic localities such as the Alcobaça Formation in Portugal, or the Yanliao Biota in China (Supplementary material). We have also included the Purbeck Group in England, which is Latest Jurassic to Early Cretaceous in age.

Below we provide comparisons for broadly contemporaneous and well-sampled vertebrate faunas from different biotas globally, beginning with the coeval Forest Marble Formation, and then looking globally at comparable sites, from the geologically oldest formation included herein (the Itat Formation in Russia) to the geologically youngest (the Purbeck Group) (Fig. 10).

\subsection{Forest Marble Formation, England}

641 The Forest Marble Formation of England yields the most similar vertebrate fauna to 642 the Kilmaluag Formation and is thought to be broadly coeval. The Forest Marble 643 Formation is part of the Great Oolite Group (Bathonian), and comprises greenish 644 grey silicate mudstones with cross-bedded limestone units and channel fills (Barron et al. 2012). It crops out across the southern half of England, but the main localities that have yielded fossil vertebrate fauna are Kirtlington Cement Quarry in Oxfordshire and Watton Cliff in Dorset (Evans 1992; Evans \& Milner 1994) (Fig. 10). 
The vertebrate beds at Kirtlington Cement Quarry near the village of Kirtlington in Oxfordshire comprise an unconsolidated brown marl, forming lenses of variable thickness between ooidal limestone (Freeman 1979). These lenses are now believed to be exhausted at surface exposure (Freeman 1979). The Forest Marble Formation at Kirtlington represents an estuarine environment, brackish to marine in nature, and to lie within the Retrocostatum to Discus Zones (possibly the Oppelia aspidoides Zone [Cope et al. 1980]), making it late Bathonian in age, although the exact dating is uncertain (Evans \& Milner 1994; Barron et al. 2012). Kirtlington Cement Quarry was collected intensively in the 1970s and 1980s, with many tonnes of matrix processed for vertebrate fossils, and it is one of the most diverse and productive microvertebrate assemblages in the UK (Evans \& Milner 1994).

The Kilmaluag Formation assemblage includes a subset of the taxa known from the Forest Marble Formation. Many of the same genera are found in both formations: the fish Hybodus and Lepidotes; the lissamphibian Marmorerpeton; the lepidosauromorph Marmoretta; the squamates Balnealacerta, Bellairsia and Parviraptor; the choristodere Cteniogenys; the mammaliamorph Stereognathus; the mammaliaforms Wareolestes rex, Borealestes and Krusatodon; and the mammalians Phascolotherium and Palaeoxonodon (Table 2 and Supplementary material). In addition, similar groups are represented at higher taxonomic levels, such as pycnodont and amiiform fishes, testudinates, goniopholid and atoposaurid crocodylomorphs, and pterosaurs. Although there is evidence of dinosaur material at both sites, most cannot be identified to a higher taxonomic level, particularly in the Kilmaluag Formation, limiting comparisons.

The similarities between these vertebrate assemblages support the hypothesis that they were deposited at approximately the same time. However, there are a few key differences between the Kilmaluag and the Forest Marble formations. Many of the same mammaliamorph and mammaliaform taxa are present in both, with the exception of haramiyids and multituberculates. These are abundant in the Forest Marble Formation—five species to date (Kermack et al. 1998; Butler \& Hooker 2005)—whereas there are currently none from the Kilmaluag Formation.

Rhynchocephalians and anurans are not currently known from the Kilmaluag Formation, but are present in the Forest Marble Formation (Evans 1992). These 
683

684

685

686

687

688

689

690

691

692

693

694

695

696

697

698

699

700

701

702

703

704

705

706

707

708

709

710

711

712

713

714

715

716

differences may be attributed to the slightly different environments represented by each: the Kilmaluag Formation is predominantly freshwater, rather than brackish or shallow marine. However, the absence of certain taxa from the Kilmaluag Formation may also be the result of differences in collection methods: bulk processing of Forest Marble sediments might have permitted a wider diversity of fauna to be recovered and identified (for more on the effects of sampling, see below).

\subsection{Guelb el Ahmar Fauna, Morocco}

The Guelb el Ahmar Fauna comes from the Middle Jurassic Anoual Formation, a predominantly continental sequence of 'red beds' located on the northeastern rim of the High Atlas Mountains (Haddoumi et al. 2016). The marine upper member of the Anoual Formation is Bathonian (Haddoumi et al. 1998), whereas the lower member represents a flood plain or deltaic depositional environment. Most vertebrate fossils located in a thin bed of dark-brown, partially lignitic marls, and the presence of palynoflora including Callaliasporites constrains the age as no older than Toarcian. (Haddoumi et al. 2016).

Both the Guelb el Ahmar Fauna and the Kilmaluag Formation include Lepidotes, albanerpetontids and other lissamphibians and caudates, testudinates, lepidosaurs including Parviraptor species, choristoderes, theropods, pterosaurs, crocodylomorphs and cladotherians (see Supplementary material). These broad similarities are also seen in the Itat Formation (see section 3.3). However, the Guelb el Ahmar Fauna is known from very incomplete material, so unlike in the Kilmaluag Formation and other better-known assemblages, most groups are represented by isolated material that cannot be assigned to genus level.

Unlike the Kilmaluag Formation, osteoglossiform, actinistan and dipnoi fish are all known from the Guelb el Ahmar Fauna. Indeterminate rhynchocephalian material is also present, as in the Forest Marble, Alcobaça and Morrison formations. The Guelb el Ahmar Fauna currently lacks several groups represented in the Kilmaluag Formation: hybodont, amiiiform and picnodont fish, sarcopterygians, paramacellodids, sauropod dinosaurs, mammaliamorphs, mammaliaforms and eutriconodont mammalians (Table 1). 
The Guelb el Ahmar Fauna is significant in that it represents one of the few Middle Jurassic assemblages from Gondwana - all of the other localities compared here are Laurasian. The similarity between the Kilmaluag Formation assemblage and fauna collected from this southern site is intriguing, as the north of Africa was separated from Europe by the emerging Central Atlantic Sea during the Middle Jurassic (Haddoumi et al. 2016). This indicates a Pangean distribution for many of these groups, and this may be supported by the fauna recovered so far from Middle Jurassic localities in Madagascar (Flynn et al. 2006) and India (Prasad \& Manhas 2002). However, the partial nature of the material from these sites limits higher taxonomic comparisons.

\subsection{Itat Formation, Russia}

Pollen from the Upper Member of the Itat Formation includes Cyathiditesminor, Piceapollenites, Eboracia, Quadraeculina, and Classopollis, which suggests a Bathonian age for this unit (Averianov et al. 2005), but possibly slightly older than either the Forest Marble or Kilmaluag formations. The Itat Formation comprises a series of fossiliferous clays, sandstones and siltstones representing a fluvial floodplain deposit (Averianov et al. 2005, 2016). The most productive site is Berezovsk Quarry in western Siberia, Russia (Fig. 10). Vertebrate fossils are found in a fluvial flood-plain deposit $\sim 50 \mathrm{~m}$ in thickness. The nature of the depositional environment is thought to contribute to the disarticulation and abrasion of specimens (Averianov et al. 2016).

The chondrichthyan fish Hybodus is the only genus present in both the Kilmaluag and Itat formations. Eodiscoglossus (anuran), which is present in the Forest Marble Formation (but not the Kilmaluag Formation), has also been found in the Itat Formation (Averianov et al. 2016). However, similar groups are represented in both the Scottish and Russian deposits: salamanders, testudines, scincoid lizards, choristoderes, lepidosauromorphs, goniopholid crocodylomorphs, pterosaurs, tritylodontid mammaliamorphs, docodontan mammaliaforms, and eutriconodont and cladotherian mammalians (see Supplementary materials).

A key difference between the Itat and Kilmaluag formations is that the former has yielded multiple haramiyidan taxa (Averianov et al. 2011, 2019), a group that is so far 
absent from the Kilmaluag Formation, although five haramiyidan species are present in the Forest Marble Formation. The Itat Formation has recently yielded two multituberculates taxa (Averianov et al. 2020), but none are present in the Kilmaluag Formation.

\subsection{Yanliao Biota, China}

The Yanliao Biota takes its name from the Yanliao area in northeast China, including parts of Inner Mongolia, and Liaoning and Hebei Provinces, which contains extensive exposures of Middle to Late Jurassic fossiliferous strata (Fig. 10). The term Yanliao Biota is used here following Xu et al. $(2016,2017)$ to include the Juilongshan/Haifenggou Formation and Tiaojishan/Lanqi Formation, as well as the 'Daohugou Biota' (Sullivan et al. 2014). The strata yielding the Daohugou Biota (including sites at Linglongta, Wubaiding, Mutoudeng, Guancaishan, Nanshimen, Daxishan, Daxigou and Youlugou) are likely to correlate with the Tiaojishan/Lanqi Formation, and possibly the youngest part of the Juilongshan/Haifenggou Formation (Sullivan et al. 2014; Xu et al. 2017). Some confusion persists over the exact correlations between different outcrops in the Yanliao area. Radiometric dates have provided a wide age range of $146-188 \mathrm{Ma}$, but a more conservative range is $157 \pm 3$ Ma (Xu et al. 2017), making it Bathonian to Oxfordian (Fig. 10). Biostratigraphical correlations support this Middle-Late Jurassic age (Sullivan et al. 2014; Xu et al. 2017).

The Yanliao Biota comes from a series of sedimentary and volcanic cycles, but despite there being multiple formations over such a large geographic area, the fossilbearing strata are somewhat similar. These mostly comprise laminated tuffaceous mudstones and shales, yielding exceptionally complete skeletons with soft tissue preservation-resulting in recognition of the sites yielding the Yanliao Biota as a globally significant Lagerstätte (Xu et al. 2017). The palaeoenvironment varied laterally, but overall represents a freshwater ecosystem similar in many ways to that preserved in the Kilmaluag Formation, but it was lacustrine rather than lagoonal, with a humid, warm climate and highly aquiferous soil (Xu et al. 2017).

No genera are shared between the Yanliao Biota and the Kilmaluag Formation, but there are some similarities in the vertebrate groups represented. Both sites have 
caudates, pterosaurs, and theropod dinosaurs, but all of these groups are represented by much higher diversity in the Yanliao Biota; conversely, squamates have a greater diversity in the Kilmaluag Formation; and docodontan mammaliaforms and eutriconodonts are similar in diversity.

Few fish have been reported from the Yanliao Biota, and fewer groups are recorded in comparison to the Kilmaluag Formation. Testudines and crocodylomorphs are also unknown in the Yanliao Biota currently. Differences in the relative abundance and presence/absence of higher taxa may reflect the continental (non-marine) nature of the Yanliao Biota, although some sampling and publication factors may partly influence their absence from faunal lists.

Similar mammaliaform and mammalian groups are present in the Yanliao Biota and the Kilmaluag, Forest Marble, and Itat formations, with multiple docodontans, one or more eutriconodontans, and at least one cladotherian (Table 2 and Supplementary material). As in the Forest Marble and Itat formations, but unlike the Kilmaluag Formation, the Yanliao Biota includes haramiyidans (e.g. Zhou et al. 2013; Xu et al. 2017). Unlike the other formations discussed so far, the Yanliao includes an australosphenidan (Pseudotribos robustus [Luo et al. 2007]). The genera represented are also exceptionally ecologically diverse, with specialised swimming (Castorocauda [Ji et al. 2006]), digging (Docofossor [Luo et al. 2015]) and gliding (Maiopatagium [Meng et al. 2017]) forms. However, this ecomorphological diversity is likely the result of the completeness of the skeletal material known for these animals-their counterparts in other localities globally are often represented by more partial cranial and dental material, which provide limited information about ecomorphology (see below for further discussion).

\subsection{The Alcobaça Formation, Portugal}

The Alcobaça Formation is Kimmeridgian in age (Fig. 10), and represents a shallowmarine to brackish deltaic depositional environment (Mateus et al. 2017). One of the most productive localities of the Alcobaça Formation is the vertebrate-bearing Guimarota Coal Mine, where it is approximately $20 \mathrm{~m}$ in thickness, comprising a layer of limestone between two coal seams (Schudack 2000). These seams are composed of alternating marls, and represent a shallow lagoon environment with 
fluctuating water levels, resulting in changes in salinity that are reflected in the evidence from ostracods and charophytes (Helmdach 1971; Schudack 2000).

Several genera are shared between the Alcobaça Formation and the Kilmaluag formations: the chondrichthyans Acrodus and Hybodus; the lepidosauromorph Marmoretta; the squamate Parviraptor, and the choristodere Cteniogenys. Similar groups are represented by different genera, for example albanerpetontids, lissamphibians of uncertain identity, paramacellodids, goniopholid and atoposaurid crocodylomorphs, pterosaurs, docodont mammaliaforms and cladotherian and eutriconodont mammals are all found in both formations. Scincoids, testudines, crocodylomorphs, pterosaurs, dinosaurs and mammalians are so far found in much greater diversity in the Alcobaça Formation. The Alcobaça Formation also includes groups not represented in the Kilmaluag Formation: multiple groups of fishes, anurans, dorsetisaurids, rhynchocephalians, multituberculates and symmetrodonts (Mateus 2006). The only groups represented in the Kilmaluag Formation that are not found in the Alcobaça Formation are sarcopterygian fishes, tritylodontids and morganucodontans.

As in most of the other sites compared herein, the Alcobaça Formation has multituberculates-in fact they represent the most speciose mammal group at this locality, with 12 genera (Martin \& Krebs 2000; Martin 2001), whereas the Kilmaluag Formation currently lacks multituberculates, indicating a substantial difference between higher taxa. The lack of haramiyidans in the Alcobaça Formation distinguishes this mammal assemblage from the Forest Marble, Itat, and Morrison formations and the Yanliao Biota and Purbeck Group (see Supplementary material).

\subsection{Morrison Formation, North America}

The Morrison Formation in North America also yields globally significant Jurassic mammal material. Historically it was one of the first Jurassic fossil localities in the world to be exploited systematically, since 1877 (Foster 2003a; Weishampel et al. 2004), and a great deal of attention has been given to its dinosaur assemblage. This rock unit extends across an enormous area of the west and central United Stateswith significant outcrops in Arizona, Montana, Wyoming, Utah, and Oklahoma-and north into Canada (Turner \& Peterson 2004). The Morrison Formation is between 
155-148 Ma (Kowallis et al. 1998; Maidment \& Muxworthy, 2019) (Fig. 10), and it largely comprises terrestrial deposits, with a huge range of lithologies including aeolian, fluvial and floodplain sandstones, floodplain/lacustrine mudstones and coal, and wetland and lacustrine carbonates (see Maidment \& Muxworthy, [2019] for comprehensive geological overview).

The only genera in common between the Kilmaluag and Morrison formations are the parviraptorid squamates, possible paramacellodids, and the choristodere Cteniogenys. However, both formations also yield: amiiform, semionotiform and pycnodont fishes; salamanders; testudinates, scincoids; goniopholid crocodiles; pterosaurs and dinosaurs; docodont mammaliaforms and eutricondont mammals (Table 2 and Supplementary material). In almost all cases, the diversity known from the Morrison Formation is much higher than the Kilmaluag Formation, especially crocodylomorphs, dinosaurs, pterosaurs and mammalians. The Morrison Formation also yields several rhynchocephalian taxa (Simpson 1926; Rasmussen \& Callison 1981; Foster 2003b; Jones et al. 2018b), which are so far unknown in the Kilmaluag Formation. The enormous extent of the Morrison Formation compared the small locality represented in Scotland by the Kilmaluag Formation undoubtedly contributes to the difference in diversity, as does the longer history of collecting in the Morrison Formation.

There are around 45 species of Mesozoic mammal known from the Morrison Formation, including eutriconodontans, docodonts, multituberculates and cladotherians (Chure et al. 2006; Supplementary material). Docodonts were among the first taxa to be found and described (Marsh 1880) and subsequently five species of the genus Docodon were erected (Marsh 1887; Simpson 1928; Rougier et al. 2015). These have since been synonymised under $D$. victor and $D$. apoxys (Chure et al. 2006; Schultz et al. 2018), which now makes Docodonta the least speciose group of Mesozoic mammals in the Morrison Formation. Nevertheless, the overall mammalian diversity is greater than the other Jurassic formations known globally (Chure et al. 2006). Like the Kilmaluag Formation, but unlike the Yanliao Biota, Forest Marble and Itat formations, there are currently no haramiyidans known from the Morrison. 
887

888

889

890

891

892

893

894

895

896

897

898

899

900

901

902

903

904

905

906

907

908

909

910

911

912

\subsection{Purbeck Group, England}

The Purbeck Group includes the Lulworth and Durlston formations, and is Tithonian to Berriasian in age (Late Jurassic to Early Cretaceous). It crops out in southern England (Fig. 10), and yields one of the most diverse vertebrate assemblages in the Mesozoic of the British Isles. The group comprises a series of interbedded mudstones, limestones and evaporites of marine, brackish and freshwater origin (Westhead \& Mather, 1996).

Although the Purbeck Group is geologically much younger than the Kilmaluag Formation (Ensom 2007), there are some similarities between the vertebrate faunas. Both sequences contain the genera Hybodus and Lepidotes, the squamate Parviraptor, paramacellodids, and several other squamate taxa. They also both have semionotiform fish; albanerpetontids, caudates, testudinates, goniopholid crocodylomorphs, pterosaurs, dinosaurs, morganucodontan and docodontan mammaliaforms, and cladotherian and eutricondont mammalians. The sampled diversity of almost all of these shared groups is far greater in the Purbeck Group.

Vertebrates represented in the Purbeck Group that are absent from the Kilmaluag Formation at present include batrachosauridid salamanders, frogs, lacertoid and dorsetisaurid squamates, rhynchocephalians, marine reptiles (plesiosaurs and ichthyosaurs), ornithischian dinosaurs, and multituberculate and symmetrodontan mammals. Groups represented in the Kilmaluag Formation that are absent from the Purbeck Group include pycnodont and sarcopterygian fish, choristoderes, and tritylodontid mammaliamorphs.

The mammaliaform orders Docodonta and Morganucodonta are much less speciose in the Purbeck Group than in the Kilmaluag Formation, contrasting with the exceptionally diverse multituberculate and cladotherian mammalians (KielanJaworowska \& Ensom 2002; Ensom 2007). This pattern is similar to that seen in the Alcobaça and Morrison formations, and may reflect the faunal replacement of earlier diverging orders with more derived mammalian groups. The presence of a possible morganucodontan in the Purbeck Group (Butler et al. 2012) is unusual, as they are entirely absent from the geologically older Alcobaça and Morrison formations, and it would represent the youngest-known occurrence of this group. 


\section{Collection Methods and Potential Biases}

The collection approach employed at Kilmaluag Formation sites since its discovery in 1971 has focussed on more complete specimens visible at outcrop, with no batch processing of bulk samples. This is partly to ensure minimal impact on the SSSI where this formation crops out, but is also influenced by the nature of the sediments. At Kirtlington Cement Quarry, Forest Marble Formation matrix was processed using a process of wet sieving followed by drying and hand picking (Freeman 1979; Evans \& Milner 1994). More complete associated skeletons would be unlikely to be retrieved using this method. A sample of matrix processed in batches by previous researchers indicated no evidence of associated remains, suggesting possible taphonomic disassociation of specimens. The same method of batch processing has been employed to process Itat Formation sediments at the Berezovsk coal mine (Averianov et al. 2016), and the Guelb el Ahmar fauna from the Anoual Formation (Haddoumi et al. 2016). Similarly, at Guimarota the coal lignite sediment of the Alcobaça Formation was dissolved in an alkaline bath and screen washed (Martin 2001)_although some more complete specimens were found in lumps of lignite prior to this process (Martin 2005). The Morrison Formation crops out in multiple localities, and these have been both screenwashed and collected by eye (Foster \& Lucas 2006; Foster \& Heckert 2011). This ability to bulk process sediments constitutes a key difference between sampling the Kilmaluag Formation and most of the other formations and vertebrate assemblages discussed herein, and limits the quantity of isolated remains that have been recovered from the Kilmalaug Formation compared to other units.

Collection from Yanliao Biota localities is usually through concentrated excavation efforts, without screen-washing, and initial discoveries come often from local farmers spotting fossil material during their work (Xu et al. 2016, 2017). Therefore, a collection bias may exist towards more complete material visible at outcrop.

The hard-weathering nature and poor reaction to acid of the limestones in the vertebrate-rich strata of the Kilmaluag Formation are not suited to bulk processing.

954 This limits the volume of fossil material collected from these outcrops, and introduces 
collection bias towards more readily visible material—such as bone associations, dentaries containing teeth, and single elements-that appear diagnostic at outcrop. Micro-CT scans of collected specimens occasionally reveal isolated dental and skeletal fragments scattered throughout the limestone matrix. These commonly include tritylodontid teeth, salamander vertebrae, and fish remains (RBJB and EP, pers. obs.). These finds suggest that if the Kilmaluag Formation could be bulk processed it would potentially yield a similarly rich assemblage of incomplete and isolated microvertebrate remains to those of the Forest Marble Formation.

There have been three main periods of collecting from the outcrops of the Kilmaluag Formation along the Strathaird Peninsula. From 1971-1982 collecting was carried out over the course of seven field trips by Michael Waldman and Robert Savage (hereafter referred to as: W\&S) and their team. In 2004 and 2006 collecting was carried out by SE and Paul Barrett (hereafter referred to as: E\&B) and their team. Collecting has been carried out since 2010 by SW, RBJB, EP and RJB and their teams (hereafter referred to as: SRER). There are marked differences in the collections made by each team (Fig. 11): W\&S collected substantially more mammaliamorphs and mammaliaforms (42\%), mainly in the form of tritylodontid teeth, whereas E\&B collected more fish $(37 \%)$, which were predominantly shark teeth. For SRER the largest proportion of finds has been lepidosaurs (21\%), including multiple dentaries and small partial skeletons (Fig. 11). Of all finds made by all teams since $1971,37 \%$ remain unidentified, usually because they are too fragmentary to assign to any taxonomic group. This figure may reduce in the next decade due to changing collection practices. Although $25 \%$ of specimens collected by SRER are categorised as 'unknown ID', many of these possess diagnostic characters and await CT-scanning to facilitate identification.

The application of micro-CT scanning as routine by SRER means collecting practices have changed dramatically. Previously mainly fossils that appeared likely to produce good specimens when observed at outcrop tended to be collected. It is now evident that the much less superficially compelling material exposed along the Strathaird Peninsula can be highly informative once $\mu \mathrm{CT}$-scanned. This is particularly true for microvertebrates such as small amphibians, reptiles and 
mammaliaforms, which may appear unpromising and indistinct even when observed under magnification.

990

\section{Discussion}

992

The Kilmaluag Formation is currently producing novel insights into the Middle Jurassic vertebrate fauna of the UK. The assemblage appears to constitute a subsample of that found within the Forest Marble Formation, but unlike those from Kirtlington Cement Quarry the specimens from the Kilmaluag Formation are most often preserved in association, preserving more complete morphology. This attribute has already permitted re-evaluation of the anatomy, taxonomy and diversity of various mammal groups (Close et al. 2016; Panciroli et al. 2017a, b, 2018b and c, 2019) and it is clear from the material currently under study that it will do the same for multiple squamate and lissamphibian clades.

1002

The new skeletal material of Marmorerpeton and 'Kirtlington salamander A' from Skye has huge potential for understanding early salamander evolution. These specimens will also be highly valuable for interpreting the taxonomy of isolated salamander material from other Middle Jurassic sites (e.g. Kirtlington). The identification of jaws and vomers remains particularly problematic (Evans et al. 1988, 1994)

The discovery of more complete skeletal material for known taxa has changed our understanding of the diversity of Middle Jurassic vertebrate assemblages in the UK. With more complete dental and skeletal material, it has been possible to clarify the amount of anatomical variation among taxa, resulting in a reduction in species diversity for some taxonomic groups (e.g. Stereognathus and Palaeoxonodon), but increases for others as new taxa are recognised that were not identifiable from less complete material (e.g. Borealestes, new salamander and reptile material).

The outcrops of the Kilmaluag Formation are in areas protected by SSSI and NCO, ensuring that only minimal collecting takes place, and only for scientific research. Due to the mode of fossil preservation and its limestone matrix, data on these fossils can only be obtained thanks to the application of micro-CT scanning as routine by 
researchers. It is vital that protections remain in place to ensure key specimens are not lost to science through destructive unauthorised collecting.

1024

1025

\section{Conclusions}

1026

The Kilmaluag Formation contains undoubtedly one of the most important vertebrate assemblages in the world. Although it appears less diverse than either the contemporaneous Forest Marble or Itat formations, the Middle-Late Jurassic Yanliao Biota, the Upper Morrison and Alcobaca formations, or the latest JurassicCretaceous Purbeck Group, this is likely partly a result of restricted outcrop and an inability to bulk process the limestone of the Kilmaluag Formation. Despite this, it contains many similar genera, and adds to our picture of the biogeographical distributions of these groups in the Middle Jurassic. The Kilmaluag Formation appears to comprise a subsample of the taxa known from the Forest Marble Formation, but this subset is represented by more complete material including partial skeletons. The ongoing protection of the sites where the Kilmaluag Formation crops out is vital. Scientific collection is selective, poses minimal impact and is producing a steady volume of material that promises more information on new, and previously poorly represented taxa. Using $\mu \mathrm{CT}$, it is possible to exploit the rare threedimensional preservation of these fossils. This combination of taxonomic diversity, completeness, and three-dimensional preservation, makes the Kilmaluag Formation one of the most important sites in the world for understanding Middle Jurassic ecosystems, as well as the anatomy and evolution of multiple major lineages of Mesozoic vertebrates.

\section{Acknowledgements}

Thanks to the John Muir Trust and Scottish Natural Heritage for permission to carry out fieldwork on Skye each year under permit, especially Ally Macaskill, Meryl Carr, Colin MacFadyen, Sarah McGrory, and Alex Turner. Thanks to the fieldwork teams that have contributed to discoveries over the years, including Jérémy Anquetin, Paul

1053 Barrett, Yves Candela, Vicen Carrió, Neil Clark, Roger Close, Sam Crehan, Rob 1054 Felix, Daniel Field, Nick Fraser, Stuart Feerick, Dave Herd, Jason Hilton, Ruben én 1055 Contreras Izquierdo, Emrys Jones, Ming-Mei Liang, Jeff Liston, Scott Moore-Fay, 
1056

1057

1058

1059

1060

1061

1062

1063

1064

1065

1066

1067

1068

1069

1070

1071

1072

1073

1074

1075

1076

1077

1078

1079

1080

1081

1082

1083

1084

1085

1086

1087

1088

Jolyon Parish, Andrew Ross, Emily Rayfield, Brigit Tronrud, Sarah Stewart and Andrzej Wolniewicz and Matt Fair and Brett Crawford from Research Casting International. We thank Scott Moore-Faye for preparation of specimens, Tom Davies, Ketura Smithson, Ian Butler, and Vincent Fernandez for access to CT facilities. We are grateful to Jérémy Anquetin, Paul Barrett and Charles Underwood for permission to use, and for providing, images. Thanks to the Natural Sciences Department at National Museums Scotland, and especially Nicholas Fraser for his comments which helped to improve this manuscript. We thank our reviewers, Paul Barrett and Pavel Skutschas, for their time providing constructive comments to improve this manuscript for publication.

\section{Funding}

EP was funded initially by NERC studentship NE/L002558/1, then as part of Leverhulme Trust grant (see below), with additional funding from the Palaeontographical Society and the Inverness Field Club. The fieldwork led by Evans and Barrett in 2004 was funded by the National Geographic Society (grant number 7583-04) and fieldwork since 2010 has been supported by National Museums of Scotland, the John Fell Fund of Oxford University and the National Geographic Society GEFNE185-16. Current fieldwork and research into Kilmaluag Formation amphibians is funded by a grant to SEE and RBJB from the Leverhulme Trust (RPG-2018-381).

\section{References}

Anderson, F. W. \& Dunham, K.C. 1966. The geology of northern Skye. Memoir of the Geological Survey of Great Britain, Sheet 80 and parts of sheets 81,90 and 91 (Scotland).

Andrews, J. E. 1985. The sedimentary facies of a late Bathonian regressive episode: the Kilmaluag and Skudiburgh Formations of the Great Estuarine Group, Inner Hebrides, Scotland. Journal of the Geological Society of London, 142, 1119-1137. 
1089 Anquetin, J. Barrett, P. M., Jones, M. E., Moore-Fay, S. and Evans, S. E. 2009. A 1090 new stem turtle from the Middle Jurassic of Scotland: new insights into the evolution and palaeoecology of basal turtles. Proceedings of the Royal Society $B, 276,879-$ 886.

1093

Anquetin, J. 2010. The anatomy of the basal turtle Eileanchelys waldmani from the

Middle Jurassic of the Isle of Skye, Scotland. Earth and Environmental Science

Transactions of the Royal Society of Edinburgh, 101, 67-96.

1097

Anquetin J. \& Claude J. 2008. Reassessment of the oldest British turtle: Protochelys from the Middle Jurassic Stonesfield Slate of Stonesfield, Oxfordshire, UK.

Geodiversitas 30, 331-344.

Averianov, A. O., Lopatin, A. V., Skutschas, P. P., Martynovich, N. V., Leshchinskiy,

S. V., Krasnolutskii, S. A. \& Fayngertz, A. V. 2005. Discovery of Middle Jurassic

Averianov, A. O., Lopatin, A. V. \& Krasnolutskii, S. A. 2011. The first haramiyid

(Mammalia, Allotheria) from the Jurassic of Russia. Doklady Biological Sciences,

437, 103-106.

Averianov, A. O., Martin, T., Skutschas, P. P., Danilov, I. G., Schultz, J., Schellhorn, R., Obraztsova, E., Lopatin, A., Sytchevskaya, E., Kuzmin, I. \& Krasnolutskii, S. 2016. Middle Jurassic vertebrate assemblage of Berezovsk coal mine in western Siberia (Russia). Global Geology, 19, 187-204.

Averianov, A. O., Martin, T., Lopatin, A. V., Schultz, J. A., Schellhorn, R.,

Krasnolutskii, S., Skutschas P. \& Ivantsov S. 2019. Haramiyidan mammals from the Middle Jurassic of Western Siberia, Russia. Part 1: Shenshouidae and 
the Middle Jurassic of western Siberia, Russia and the origin of multituberculata.

Papers in Palaeontology, 1-19. [in press]

Barrett, P. M. 2006. A sauropod dinosaur tooth from the Middle Jurassic of Skye, Scotland. Transactions of the Royal Society of Edinburgh: Earth Sciences, 97, 2529.

Barron, A. J. M., Lott, G. K. \& Riding, J. B. 2012. Stratigraphic Framework for the Middle Jurassic Strata of Great Britain and the Adjoining Continental Shelf: Research Report RR/11/06. British Geological Survey, Keyworth. 177 pp.

Benson, R. B. 2018. Dinosaur macroevolution and macroecology. Annual Review of Ecology, Evolution, and Systematics, 49: 379-408.

Benson, R. B. J., Campione, N. E., Carrano, M. T., Mannion, P. D., Sullivan, C., Upchurch, P. \& Evans, D. C. 2014. Rates of dinosaur body mass evolution indicate 170 million years of sustained ecological innovation on the avian lineage. PLOS Biology, 12, e1001853.

Blake, C. C. 1863. On chelonian scutes from the Stonesfield Slate. The Geologist 6, 183-184.

Buckland, W. 1824. Notice on the Megalosaurus or great Fossil Lizard of Stonesfield. Transactions of the Geological Society of London, 2, 390-396.

Burbrink, F.T., Grazziotin, F.G., Pyron, R.A., Cundall, D., Donnellan, S., Irish, F., Keogh, J.S., Kraus, F., Murphy, R.W., Noonan, B. \& Raxworthy, C.J. 2019. Interrogating genomic-scale data for Squamata (lizards, snakes, and amphisbaenians) shows no support for key traditional morphological relationships. Systematic Biology, 69, 1-19.

Butler, P. M. 1939. The teeth of the Jurassic mammals. Proceedings of the Zoolological Society of London, 109, 329-356. 
1156 Butler, P. M. \& Hooker, J. J. 2005. New teeth of allotherian mammals from the 1157 English Bathonian, including the earliest multituberculates. Acta Palaeontologica 1158 Polonica, 50, 185-207.

1160 Butler, P. M. \& Sigogneau-Russell, D. 2016. Diversity of triconodonts in the Middle 1161 Jurassic of Great Britain. Palaeontologia Polonica, 67, 35-65.

1162

Butler, P.M. Sigogneau-Russell, D. \& Ensom, P.C. 2012. Possible persistence of the 1164 morganucodontans in the Lower Cretaceous Purbeck Limestone Group (Dorset, 1165 England). Cretaceous Research, 33, 135-145.

Caldwell, M.W., Nydam, R.L., Palci, A. \& Apesteguía, S. 2015. The oldest known snakes from the Middle Jurassic-Lower Cretaceous provide insights on snake evolution. Nature communications, 6, 1-11.

Chen, P.-J., \& Hudson, J. D., 1991. The conchostracan fauna of the Great Estuarine Group, Middle Jurassic, Scotland. Palaeontology, 34, 515-545.

Chure, D. J., Litwin, R., Hasiotis, S. T., Evanoff, E. \& Carpenter, K. 2006. The fauna and flora of the Morrison Formation. New Mexico Museum of Natural History and Science Bulletin, 36, 233-249.

Clark, N. D. L. 2018. Review of the Dinosaur Remains from the Middle Jurassic of Scotland, UK. Geosciences, 8, 53.

Clark, N. D. L., Ross, D. A., \& Booth, P. 2005. Dinosaur tracks from the Kilmaluag Formation (Bathonian, Middle Jurassic) of Score Bay, Isle of Skye, Scotland, UK. Ichnos, 12, 93-104.

Close, R. A., Davis, B. M., Walsh, S., Woloniewicz, A. S., Friedman, M., \& Benson, R. B. J. 2016. A lower jaw of Palaeoxonodon from the Middle Jurassic of the Isle of Skye, Scotland, sheds new light on the diversity of British stem therians.

Palaeontology, 59, 155-169. 
1190 Cohen, K. M., Harper, D. A. T., Gibbard, P. L., \& Fan, J. -X. 2019. International

Chronostratigraphic Chart. International Commission of Stratigraphy.

1192

1193

Cope, J. C. W., Dufl, K. L., Parsons, C. F., Torrens, H. S., Wimbledon, W. A. \&

Wright, J. 1980. A Correlation of Jurassic Rocks in the British Isles. Pt. 2: Middle and

Upper Jurassic. Geological Society Special Report 15. 109 pp.

1196

1197

Delair, J.B. \& Sarjeant, W.A. 2002. The earliest discoveries of dinosaurs: the records

re-examined. Proceedings of the Geologists' Association, 113, 185-197.

1199

1200

Ensom, P. C. 2007. The Purbeck Limestone Group of Dorset, southern England.

1201 Geology Today, 23, 178-185.

1202

1203

Evans, S. E. 1989. New material of Cteniogenys (Reptilia: Diapsida) and a reassessment of the systematic position of the genus. Neues Jahrbuch für Geologie und Paläontologie,

Abhandlungen, 181, 577-589.

1206

1207

Evans, S.E., 1990. The skull of Cteniogenys, a choristodere (Reptilia:

1208

Archosauromorpha) from the Middle Jurassic of Oxfordshire. Zoological Journal of the Linnean Society, 99, 205-237.

Evans, S.E., 1991a. A new lizard-like reptile (Diapsida: Lepidosauromorpha) from the Middle Jurassic of England. Zoological Journal of the Linnean Society, 103, 391-412 .

Evans, S.E., 1991b. The postcranial skeleton of the choristodere Cteniogenys (Reptilia: Diapsida) from the Middle Jurassic of England. Geobios, 24, 187-199.

Evans, S.E. 1992. A sphenodontian (Reptilia: Lepidosauria) from the Middle Jurassic of England. Neues Jahrbuch für Geologie und Paläontologie Abhandlungen, 1992, 449-457.

Evans, SE 1994. A new anguimorph lizard from the Jurassic and Lower Cretaceous of England. Palaeontology, 37, 33-49. 
1225 Evans, S.E. 1996. Parviraptor (Squamata: Anguimorpha) and other lizards from the

1226

1227

1228

1229

1230

1231

1232

1233

1234

1235

1236

1237

1238

1239

1240

1241

1242

1243

1244

1245

1246

1247

1248

1249

1250

1251

1252

1253

1254

1255

1256

Morrison Formation at Fruita, Colorado. Museum of Northern Arizona Bulletin, 60, 243-248.

Evans, S. E. 1998. Crown group lizards (Reptilia, Squamata) from the middle Jurassic of the British Isles. Palaeontographica Abteilung A-Stuttgart, 250, 123-154.

Evans, S. E. \& Milner, A. R. 1994. Middle Jurassic microvertebrate assemblages from the British Isles. In: Fraser, N. C. and Sues, H. -D. (eds) In the Shadow of the

Dinosaurs: Early Mesozoic tetrapods. Cambridge University Press, Cambridge, 303321

Evans, S.E. \& Waldman, M. 1996. Small reptiles and amphibians from the Middle Jurassic of Skye, Scotland. The continental Jurassic. Museum of Northern Arizona, Bulletin, 60, 219-226.

Evans, S. E. \& Chure, D. C. 1998 Paramacellodid lizard skulls from the Jurassic Morrison Formation at Dinosaur national monument, Utah. Journal of Vertebrate Paleontology, 18, 99-114

Evans, S.E., Milner, A.R. \& Mussett, F. 1988. The earliest known salamanders (Amphibia, Caudata): a record from the Middle Jurassic of England. Geobios, 21, 539-552.

Evans, S. E., Milner A. R., \& Mussett F. 1990. A discoglossid frog from the Middle Jurassic of England. Palaeontology, 33, 299-311.

Evans, S., Barrett, P., Hilton, J., Butler R. J., Jones, M. E. H., Liang, M. -M., Parrish, J. C., Rayfield, E. J., Sigogneau-Russell, D. \& Underwood, C. J. 2006. The Middle Jurassic vertebrate assemblage of Skye, Scotland. In: Barrett, P. \& Evans, S. (eds) Proceedings of the Ninth Symposium on Mesozoic Terrestrial Ecosystems and Biota, Natural History Museum, London, 36-39. 
1257 Foster, J.R. 2003a. Paleoecological analysis of the vertebrate fauna of the Morrison

1258 Formation (Upper Jurassic), Rocky Mountain region, U.S.A. New Mexico Museum of

1259 Natural History \& Science Bulletin 23, 1-95.

1260

1261 Foster J. 2003b. New specimens of Eilenodon (Reptilia, Sphenodontia) from the

1262 Morrison Formation (Upper Jurassic) of Colorado and Utah. Brigham Young

1263 University Geological Studies, 47, 17-22.

1264

1265

Foster, J. R. \& Heckert, A. B., 2011. Ichthyoliths and other microvertebrate remains

1266

from the Morrison Formation (Upper Jurassic) of northeastern Wyoming: a screen-

1267

washed sample indicates a significant aquatic component to the fauna.

1268 Palaeogeography, Palaeoclimatology, Palaeoecology, 305, 264-279.

1269

1270

Foster, J. R. \& Lucas, S. G. 2006. Paleontology and Geology of the Upper Jurassic

1271

Morrison Formation: Bulletin 36. New Mexico Museum of Natural History and

1272

Science, 249 pp.

1273

1274

Freeman, E.F. 1976. Mammal teeth from the Forest Marble (Middle Jurassic) of

1275

Oxfordshire, England. Science, 194, 1053-1055.

1276

1277

Freeman, E.F. 1979. A Middle Jurassic mammal bed from Oxfordshire.

1278

Palaeontology, 22, 135-166.

1279

1280

Gao, K-Q, \& Shubin, N. H. 2012. Late Jurassic salamandroid from western Liaoning,

1281

China. Proceedings of the National Academy of Sciences, 109, 5767-5772.

1282

1283

Gardner, J., Evans, S.E., \& Sigogneau-Russell, D. 2003. Albanerpetontid amphibians from the Early Cretaceous of Morocco and the Middle Jurassic of

England. Acta Palaeontologia Polonica, 48, 301-319.

1286

1287

Gillham, C. 1994: A fossil turtle (Reptilia: Chelonia) from the Middle Jurassic of

1288 Oxfordshire, England. Neues Jahrbuch der Geologie und Paläontologie.

1289 Monatshefte, 10, 581-596. 
1291 Haddoumi, H., Aiméras, Y., Bodergat, A. M., Charrière, A., Mangold, C. \& Benshili, K. 1998. Âges et environnements des Couches rouges d'Anoual (Jurassique moyen et Crétacé inférieur, Haut-Atlas oriental, Maroc). Comptes Rendus de l'Académie des Sciences-Series IIA-Earth and Planetary Science, 327, 127-133.

1295

Haddoumi, H., Allain, R., Meslouh, S., Metais, G., Monbaron, M., Pons, D., Rage, J. C., Vullo, R., Zouhri, S. \& Gheerbrant, E. 2016. Guelb el Ahmar (Bathonian, Anoual Syncline, eastern Morocco): first continental flora and fauna including mammals from 1299 the Middle Jurassic of Africa. Gondwana Research, 29, 290-319.

1300

1301

Hahn, G., Sigogneau- Russell, D. \& Godefroit, P. 1991. New data on

1302

Brachyzostrodon (Mammalia; Upper Triassic). Geologica et Paleontologica, 25, 2371303 249.

1304

1305

Harris, J. P. \& Hudson, J. D. 1980. Lithostratigraphy of the Great Estuarine Group 1306 (Middle Jurassic), Inner Hebrides. Scottish Journal of Geology, 16, 231-250.

Helmdach, F. F. 1971. Stratigraphy and ostracode-fauna from the coal mine

Guimarota (Upper Jurassic). Memórias dos Serviços Geológicos de Portugal, N.S.,

Hesselbo, S. P. \& Coe, A. L. 2000. Jurassic sequences of the Hebrides Basin, Isle of

Ivakhnenko M. 1978. Urodeles from the Triassic and Jurassic of Soviet Central Asia. Palaeontologicheski Zhurnal, 84-89. [in Russian]. 
1323 Jones, M.E., Anderson, C.L., Hipsley, C.A., Müller, J., Evans, S.E. \& Schoch, R.R., 1324 2013. Integration of molecules and new fossils supports a Triassic origin for

1325 1326

1327

1328

1329

1330

1331

1332

1333

1334

1335

1336

1337

1338

1339

1340

1341

1342

1343

1344

1345

1346

1347

1348

1349

1350

1351

1352

1353

1354

1355

1356

Lepidosauria (lizards, snakes, and tuatara). BMC Evolutionary Biology, 13, 208.

Jones, M. E. H., Hill, L. E., Benson, R. B., \& Evans, S. E. 2018a. Three dimensional skeletons of middle Jurassic stem-group salamanders from Scotland, UK. Journal of Vertebrate Paleontology, Program and Abstracts, 2018, 126.

Jones, M.E., Lucas, P.W., Tucker, A.S., Watson, A.P., Sertich, J.J., Foster, J.R., Williams, R., Garbe, U., Bevitt, J.J. \& Salvemini, F. 2018. Neutron scanning reveals unexpected complexity in the enamel thickness of an herbivorous Jurassic reptile. Journal of The Royal Society Interface, 15, 20180039.

Judd, J. W. 1878. The secondary rocks of Scotland. Third paper. The strata of the western coasts and islands. Quarterly Journal of the Geological Society of London, $34,660-743$.

Kielan-Jaworowska, Z. \& Ensom, P. C. 1992. Multituberculate mammals from the Upper Jurassic Purbeck Limestone formation of southern England. Palaeontology, $35,95-126$.

Kermack, K.A., Lee, A.J., Lees, P.M. \& Mussett, F., 1987. A new docodont from the Forest Marble. Zoological Journal of the Linnean Society, 89, 1-39.

Kermack, K. A., Kermack, D. M., Lees, P. M. \& Mills, J. R. 1998. New multituberculate-like teeth from the Middle Jurassic of England. Acta Palaeontologica Polonica, 43, 581-606.

Kowallis, B. J., Christiansen, E. H., Deino, A. L., Peterson, F., Turner, C. E., Kunk, M. J. \& Obradovich, J. D. 1998. The age of the Morrison Formation. Modern Geology, 22, 235-260.

Kühne, W. G. 1956. The Liassic therapsid Oligokyphus. British Museum (Natural History), London, 149 pp.

41 of 52 
1357

1358

Lee, M. S., Cau, A., Naish, D. \& Dyke, G. J. 2014. Sustained miniaturization and

1359

anatomical innovation in the dinosaurian ancestors of birds. Science, 345, 562-566.

1360

1361

1362

Luo, Z. -X. 2007. Transformation and diversification in early mammal evolution.

Nature, 450, 1011-1019.

1363

1364

1365

Luo, Z. -X. \& Martin, T. 2007. Analysis of molar structure and phylogeny of

docodontan genera. Bulletin of Carnegie Museum of Natural History, 39, 27-47.

1366

1367

Luo, Z. -X., Ji, Q., \& Yuan, C. -X. 2007. Convergent dental adaptations in pseudo-

1368

tribosphenic and tribosphenic mammals. Nature Letters, 450, 93-97.

1369

1370

Luo, Z. -X., Meng, Q. -J., Ji, Q., Liu, D., Zhang, Y. -G. \& Neander, A. I. 2015.

1371

Evolutionary development in basal mammaliaforms as revealed by a docodontan.

1372

Science, 347, 760-764.

1373

McGowan, G. J. 1996. Albanerpetontid amphibians from the Jurassic (Bathonian) of

Southern England. Museum of Northern Arizona Bulletin, 60, 227-234.

1376

Maidment, S.C. \& Muxworthy, A. 2019. A chronostratigraphic framework for the Upper Jurassic Morrison Formation, western USA. Journal of Sedimentary

Marjanović, D. \& Laurin, M. 2014. An updated paleontological timetree of lissamphibians, with comments on the anatomy of Jurassic crown-group salamanders (Urodela). Historical Biology, 26, 535-550.

Marsh, O. C. 1880. Notice on Jurassic mammals representing two new orders.

American Journal of Science, 20, 235-239

Marsh, O. C. 1887 American Jurassic Mammals. American Journal of Science, 33, 
1391

1392

1393

1394

1395

1396

1397

1398

1399

1400

1401

1402

1403

1404

1405

1406

1407

1408

1409

1410

1411

1412

1413

1414

1415

1416

1417

1418

1419

1420

1421

1422

1423

1424

Marshall, P. 2003. Ichnofossils of the Psilonichnus Ichnofacies and their paleoecological and paleoenvironmental significance in the Scottish Middle Jurassic. Ichnos, 9, 95-108.

Martin, T. 2001. Mammalian fauna of the Late Jurassic Guimarota ecosystem. Publicación Electrónica de la Asociación Paleontológica Argentina, 7, 1.

Martin, T. 2005. Postcranial anatomy of Haldanodon exspectatus (Mammalia, Docodonta) from the Late Jurassic (Kimmeridgian) of Portugal and its bearing for mammalian evolution. Zoological Journal of the Linnean Society, 145, 219-248.

Martin, T. \& Krebs, B. 2000. Guimarota A Jurassic Ecosystem. Verlag, Munich, Germany.

Martin-Silverstone, E. G., Unwin, D. M. \& Barrett, P. M. 2018. A new threedimensionally preserved monofenestratan pterosaur from the Middle Jurassic of Scotland and the complex evolutionary history of the scapula-vertebral articulation. Symposium of Vertebrate Paleontology Meeting 2019 Programme and Abstracts, Brisbane, Australia, p150.

Mateus, O. 2006. Late Jurassic dinosaurs from the Morrison Formation, the Lourinhã and Alcobaça Formations (Portugal), and the Tendaguru Beds (Tanzania): a comparison. In: Foster, J.R. and Lucas, S. G. R.M. (eds) Paleontology and Geology of the Upper Jurassic Morrison Formation. New Mexico Museum of Natural History and Science Bulletin 36, 223-231.

Mateus, O., Dinis, J. \& Cunha, P.P. 2017. The Lourinhã Formation: the Upper Jurassic to lower most Cretaceous of the Lusitanian Basin, Portugal-landscapes where dinosaurs walked. Ciências da Terra/Earth Sciences Journal, 19, 75-97. Mellere, D. \& Steel, R. J. 1996. Tidal sedimentation in Inner Hebrides half grabens, Scotland: The Mid-Jurassic Bearreraig Sandstone Formation. In: DeBatist, M. and Jacobs, P. (eds) Geology of Siliciclastic Shelf Seas. Geological Society, London, Special Publications, 117, 49-79 
Meng, Q. -J., Grossnickle, D. M., Liu, D., Zhang, Y.G., Neander, A.I., Ji, Q. and Luo,

Z.X. 2017. New gliding mammaliaforms from the Jurassic. Nature, 548: 291-296.

Morton, N. 1987. Jurassic subsidence history in the Hebrides, NW Scotland. Marine and Petroleum Geology, 4, 226-242.

Morton, N., \& Hudson J. D. 1995. Field guide to the Jurassic of the Isles of Raasay and Skye, Inner Hebrides, NW Scotland. In: Taylor, P. D. (ed). Field Geology of the

British Jurassic. Geological Society, London, 209-280.

Nesov, L.A. 1988. Late Mesozoic amphibians and lizards of Soviet Middle Asia. Acta Zoologica Cracoviensia 31,475-486.

Nesov, L. A., Fedorov, P. V., Potapov, D. O., \& Golovnyeva, L. S. 1996. The structure of the skulls of caudate amphibians collected from the Jurassic of

Kirgizstan and the Cretaceous of Uzbekistan (in Russian). Vestnik Sankt-

Petersburgskogo Universiteta, Seriya 7, Geologiya, Geografiya 1, 3-11

Panciroli, E., Benson, R. B. J. \& Walsh, S. 2017a. The dentary of Wareolestes rex (Megazostrodontidae): a new specimen from Scotland and implications for morganucodontan tooth replacement. Papers in Palaeontology, 3, 373-386.

Panciroli, E., Walsh, S., Fraser, N., Brusatte, S. L. \& Corfe, I. 2017b. A

reassessment of the postcanine dentition and systematics of the tritylodontid Stereognathus (Cynodontia, Tritylodontidae, Mammaliamorpha), from the Middle Jurassic of the UK. Journal of Vertebrate Paleontology, 37, 373-386.

Panciroli, E. P., Benson, R. B. J., \& Walsh, S. 2018a. The Mammal-Rich Freshwater Assemblage of the Middle Jurassic Kilmaluag Formation, Isle of Skye, Scotland. Abstracts of the 13th Symposium on Mesozoic Terrestrial Ecosystems, Bonn, 
1458 Panciroli E., Benson, R. B. J. \& Butler R. J. 2018b. New partial dentaries of 1459 Palaeoxonodon ooliticus (Mammalia, Amphitheriidae) from Scotland, and posterior dentary morphology in stem cladotherians. Acta Paleontologica Polonica, 63, 197206.

Panciroli, E., Schultz, J. A. \& Luo, Z. -X. 2018c. Morphology of the petrosal and stapes of Borealestes (Mammaliaformes, Docodonta) from the Middle Jurassic of Skye, Scotland. Papers in Palaeontology, 5, 139-156.

1466

Panciroli, E., Benson, R. B. J. \& Luo, Z. -X. 2019. The mandible and dentition of Borealestes serendipitus (Docodonta) from the Middle Jurassic of Skye, Scotland. Journal of Vertebrate Paleontology, 39, e1621884

DOI:10.1080/02724634.2019.162188

Panciroli, E., Benson, R. B. J., Fernandez, V., Butler, R. J., Fraser, N. C., Luo, Z-. X.

\& Walsh, S. in review. New species of mammaliaform and the cranium of Isles. Zoological Journal of the Linnean Society.

Rasmussen, T. E., \& Callison, G. 1981. A new herbivorous sphenodontid (Rhynchocephalia: Reptilia) from the Jurassic of Colorado. Journal of Paleontology, 55, 1109-1116.

Rauhut, O. W., Hübner, T. \& Lanser, K. P. 2016. A new megalosaurid theropod dinosaur from the late Middle Jurassic (Callovian) of north-western Germany: Implications for theropod evolution and faunal turnover in the Jurassic. Palaeontologia Electronica, 19, 1-65.

Rees, J. \& Underwood, C. J. 2005. Hybodont sharks from the Middle Jurassic of the Inner Hebrides, Scotland. Earth and Environmental Science Transactions of the Royal Society of Edinburgh, 96, 351-363. 
1493 Roelants, K., Gower, D.J., Wilkinson, M., Loader, S.P., Biju, S.D., Guillaume, K., 1494 Moriau, L. \& Bossuyt, F., 2007. Global patterns of diversification in the history of modern amphibians. Proceedings of the National Academy of Sciences, USA, 104, 887-892.

Rougier, G. W., Sheth, A. S., Carpenter, K., Appella-Guisafre, L. \& Davis, B. M. 1499 2015. A new species of Docodon (Mammaliaformes, Docodonta) from the Upper Jurassic Morrison Formation and a reassessment of selected craniodental characters in basal mammaliaforms. Journal of Mammalian Evolution, 22, 1-16.

Scheyer, T.M. \& Anquetin, J. 2008. Bone histology of the Middle Jurassic turtle shell 1504 remains from Kirtlington, Oxfordshire, England. Lethaia, 41, 85-96.

1505

1506

Schudack, M. E. 2000. Geological setting and dating of the Guimarota-beds. In:

1507

Martin, T. and Krebs, B (eds) Guimarota A Jurassic Ecosystem. Verlag, Munich, 1508 Germany, 21-26.

Schultz, J. A., Bhullar, B. A. S. \& Luo, Z. -X., 2017. Re-examination of the Jurassic mammaliaform Docodon victor by computed tomography and occlusal functional analysis. Journal of Mammalian Evolution, 26, 9-38.

Seiffert, J. 1973. Contribuição para o conhecimento da Fauna da Mina de Lignito Guimarota, 3 : Upper Jurassic lizards from Central Portugal. Serv. Geol. Portugal, 22, 7-85.

Sigogneau-Russell, D. 1998. Discovery of a Late Jurassic Chinese mammal in the upper Bathonian of England. Comptes Rendus de l'Académie des Sciences-Series IIA-Earth and Planetary Science 327, 571-576. 
1525

1526

1527

1528

1529

1530

1531

1532

1533

1534

1535

1536

1537

1538

1539

1540

1541

1542

1543

1544

1545

1546

1547

1548

1549

1550

1551

1552

1553

1554

1555

1556

1557

Sigogneau-Russell, D. 2003b. Holotherian mammals from the Forest Marble (Middle Jurassic of England). Geodiversitas, 25, 501-537.

Simpson, G.G. 1926. American terrestrial Rhynchocephalia. American Journal of Science 67, 12-16.

Simpson, G. G. 1928. A Catalogue of the Mesozoic Mammalia in the Geological Department of the British Museum. British Museum (Natural History), London. 215 pp.

Skutschas P.P. 2013. Mesozoic salamanders and albanerpetontids of Middle Asia, Kazakhstan, and Siberia. Palaeobiodiversity and Palaeoenvironments, 93, 441-457.

Skutschas, P.P. 2014a. Kiyatriton leshchinskiyi Averianov et Voronkevich, 2001, a crown-group salamander from the Lower Cretaceous of Western Siberia, Russia. Cretaceous Research, 51, 88-94.

\section{Skutschas, P.P. 2014b. A relict stem salamander: evidence from the Early} Cretaceous of Siberia. Acta Palaeontologica Polonica, 61,119-123.

Skutschas, P. P. \& Krasnolutskii S. A. 2011. A new genus and species of basal salamanders from the Middle Jurassic of Western Siberia, Russia. Proceedings of the Zoological Institute RAS 315, 167-175.

Skutschas P.P. \& Martin T. 2011. Cranial anatomy of the stem salamander Kokartus honorarius (Amphibia: Caudata) from the Middle Jurassic of Kyrgyzstan. Zoological Journal of the Linnean Society, 161, 816-838.

Skutschas, P.P., Kolchanov, V.V., Averianov, A.O., Martin, T., Schellhorn, R., Kolosov, P.N. \& Vitenko, D.D., 2018. A new relict stem salamander from the Early Cretaceous of Yakutia, Siberian Russia. Acta Palaeontologica Polonica, 63, 519525. 
1558 Sullivan, C., Wang, Y., Hone, D. W. E., Wang, Y., Xu, X. \& Shang, F. 2014. The 1559 vertebrates of the Jurassic Daohugou biota of Northeastern China. Journal of 1560 Vertebrate Paleontology, 34, 243-280.

1561

Turner, C. E. \& Peterson, F. 2004. Reconstruction of the Upper Jurassic Morrison Formation extinct ecosystem-a synthesis. Sedimentary Geology, 167, 309-355. 1564

1565 1566

Wakefield, M. I. 1995. Ostracod biostratinomy at lagoonal shorelines: examples from the Great Estuarine Group, Middle Jurassic, Scotland. Proceedings of the 1567 Geologists' Association, 106, 211-218.

Waldman, M. \& Evans, S.E. 1994. Lepidosauromorph reptiles from the Middle 1570 Jurassic of Skye. Zoological Journal of the Linnean Society, 112, 135-150.

Waldman, M. \& Savage, R. J. G. 1972. The first Jurassic mammal from Scotland. Journal of the Geological Society of London, 128, 119-125.

1574

Ward, D. J. 1984. Collecting isolated microvertebrate fossils. Zoological Journal of the Linnean Society, 82, 245-259.

Weishampel, D. B., Dodson, P. \& Osmolska, H. 2004. The Dinosauria, $2^{\text {nd }}$ edition. University of California Press, Berkeley. 861 pp.

Westhead, R. K. \& Mather, A. E. 1996. An updated lithostratigraphy for the Purbeck Limestone Group in the Dorset type-area. Proceedings of the Geologists' Association, 107, 117-128.

1584

Whyte, S. \& Ross, D. 2019. Jurassic Skye: Dinosaurs and other fossils of the Isle of 1586 Skye. NatureBureau, Berkshire. 62 pp. material from the Middle Jurassic (Bathonian) Kilmaluag Formation, Skye, Scotland. Scottish Journal of Geology, 50, 183-190. 
1592 Wills, S., Bernard, E. L., Brewer, P., Underwood, C. J. \& Ward, D. J. 2019.

1593 Palaeontology, stratigraphy and sedimentology of Woodeaton Quarry (Oxfordshire)

1594 and a new microvertebrate site from the White Limestone Formation (Bathonian,

1595 Jurassic). Proceedings of the Geologists' Association, 130, 170-186.

1596

1597 Xu, X., Zhou, Z. H., Sullivan, C., Wang, Y. \& Ren, D. 2016. An updated review of the 1598 Middle-Jurassic Yanliao Biota: chronology, taphonomy, paleontology, and 1599 paleoecology. Acta Geologica Sinica (English Edition), 90, 1801-1840.

1600

1601 Xu, X., Zhou, Z., Sullivan, C. \& Wang, Y. 2017. The Yanliao Biota: a trove of 1602 exceptionally preserved Middle-Late Jurassic terrestrial life forms. In: Fraser, N.C. 1603 and Sues, H-. D. (eds) Terrestrial Conservation Lagerstätten. Dunedin Academic 1604 Press, London, 131-167.

1605

Zhou, C. F., Wu, S., Martin, T. \& Luo, Z. -X. 2013. A Jurassic mammaliaform and the earliest mammalian evolutionary adaptations. Nature, 500, 163-167. 
1611

1612

1613

1614

1615

1616

1617

1618

1619

1620

1621

1622

1623

1624

1625

1626

1627

1628

1629

1630

1631

1632

1633

1634

1635

1636

1637

1638

1639

1640

1641

1642

1643

1644

\section{Figure captions}

Figure 1. The location of surface outcrops of the Kilmaluag Formation and overview of the stratigraphy of the Great Estuarine Group (A). Outcrops north of Elgol (B), and the appearance of bone (black) against the micritic blue-grey limestone (C). Map adapted from Wikimedia Commons. Stratigraphy compiled and adapted from Cohen et al. (2018), Andrews (1985), and Barron et al. (2012).

Figure 2. Stratigraphy of the Kilmaluag Formation at two main fossil collection sites on the Strathaird Peninsula. Adapted from Andrews (1985).

Figure 3. Invertebrate fossils in the Kilmaluag Formation: Viviparus (A); ostracods (B); hybodont shark Acrodus caledonicus NHMUK PV6642 (C) (adapted from Rees \& Underwood [2006; fig 5]); and an identified fish fossil in situ (D). Scale bars for (C) and $(D)=10 \mathrm{~mm}$.

Figure 4. Amphibians. Premaxillae of Albanerpetontidae cf. Anoulerpeton priscus NMS G.2019.34.6 in lingual (A), labial (B), and occlusal view (C). Marmorerpeton roofing bone (field number ELGOL.2019.15) in dorsal view (D). Partial atlas of Marmorerpeton (ELGOL.2016.019) in rostral view with left right side reflected to represent the right side (D). Dorsal vertebra of Marmorerpeton (ELGOL.2016.024) in rostral view $(F)$ and left lateral view $(G)$. Atlas of 'Salamander A' (field number ELGOL.2016.004) in rostral view $(\mathrm{H})$ and left lateral view (I). Dorsal vertebra of 'Salamander A' (field number ELGOL.2016.004) shown in anterior $(\mathrm{J})$ and left lateral

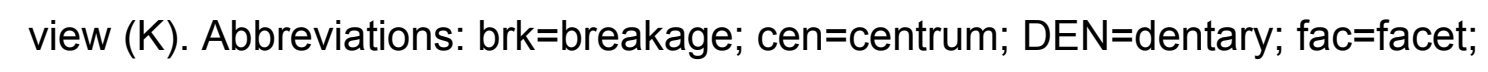
fac.pro=facial process; for=foramen; fu.sut.se= fused suture seam; lin.sh= lingual shelf; MAX=maxilla; Mck.gro=Meckelian groove; muc.sca=muscle scar; nar=naris; neu.arc=neural arch; not.can= notochordal canal; neu.cre=neural crest; pmx.fact=premaxilla facet; prezyg=presygapophyses; PRF=prefrontal; res.pit=resorption pit; rib.ber=rib bearer; spl.fac=splenial facet; sub.sh=subdental shelf; sym=symphysis; too=tooth; tr.pro=transverse process. All scale bars $=1 \mathrm{~mm}$.

Figure 5. Lepidosauromorphs from the Kilmaluag Formation: Marmoretta NMS G.1992.47.4 in lingual (A), apical (B) and labial (C) view; Lepidosauromorph 'species 
A' NMS G.2019.34.9 in lingual (D), labial (E) and apical (H) views; and Lepidosauromorph 'species B' NMS G.2019.34.13 in lingual (F), labial (G) and apical (I) views. Abbreviations as for Fig. 4 . Scale bar $=5 \mathrm{~mm}$.

Figure 6. Squamates: tricuspid squamate dentary, NMS G.1992.47.125 in lingual (A) and labial (B) views; Squamata cf. Paramacellodidae NMS G.2019.34.11 in lingual (C) labial (D) and apical view (E). Abbreviations as for Fig. 4. Scale bar $=5 \mathrm{~mm}$.

Figure 7. Squamates from the Kilmaluag Formation: Balnealacerta silvestris NMS G.2019.34.3 dentary and partial maxilla (A), with the dentary in lingual (B), labial (C), and apical $(D)$ views, and maxilla in lingual $(E)$, labial $(F)$, and apical $(G)$ views; Bellairsia gracilis NMS G.2019.34.1 in labial ( $\mathrm{H}$ and $\mathrm{I}$ ), lingual ( $\mathrm{J}$ and $\mathrm{K}$ ), and apical $(L$ and $M)$ views. Abbreviations as for Fig. 4. Scale bar $=5 \mathrm{~mm}$.

Figure 8. Reptile fossils from the Kilmaluag Formation: turtle Eileanchelys waldmani NMS G.2004.31.16d (A) (image: J. Anquetin); crocodylomorph osteoderms NHMUK PV R36713 (B) (adapted from Wills et al. [2014; fig 4a]); sauropod dinosaur tooth NMS G.2004.31.1 (C) (adapted from Barrett [2006: fig 1]); and a non-pterodactyloid pterosaur collected in 2016 (D) (Photo by R Close). Scale bars: $B=50 \mathrm{~mm}$, for $\mathrm{C}=5$ $\mathrm{mm}$.

Figure 9. Mammaliamorphs from the Kilmaluag Formation: Stereognathus ooliticus NMS G.2017.17.2 (A), and NMS G.1992.47.120 (B) (adapted from Panciroli et al. [2017b;5 and 7]); Wareolestes rex NMS G.2016.34.1, photographed in matrix (C), digitally segmented in labial view (D) and lingual view (E) (adapted from Panciroli et al. [2017; fig 2 and 3]); Palaeoxonodon ooliticus NMS G.2016.17.1 in the field (F) (image: R. Close), and combined with NMS G.2017.37.1 (red) in labial (G) and lingual view (H); Palaeoxonodon ooliticus NMS G.1992.47.123 in labial (I) and lingual view (J) (adapted from Panciroli et al. [2018a; figs 1 and 3]); Borealestes serendipitus BRSUG 20570 holotype (K), Borealestes serendipitus NMS G.1992.47.121.3 in lingual (L) and labial view (M); Phascolotherium sp. (field number ELGOL2017.023) in labial view (N). Abbreviations: dent.cond=dentary condyle; mass.foss=masseteric fossa; man.sym=mandibular symphysis; Mck.gro=Meckelian groove. Scale bar $=5 \mathrm{~mm}$, same scale throughout. 
1679

1680 Figure 10. Location and age of the Jurassic and Cretaceous vertebrate 1681 assemblages discussed.

1682

1683 Figure 11. Proportion of each vertebrate group collected by research teams from the 1684 Kilmaluag Formation: since the sites discovery in 1971 (A); in the 1970-80s by Dr 1685 Michael Waldman and Prof Robert Savage (B); in the early 2000s by Prof Susan 1686 Evans and Prof Paul Barrett (C); and since 2010 by the universities of Oxford, 1687 Birmingham, and National Museums Scotland (D). Silhouettes created by EP. 1688

1689 Table 1: Updated vertebrate faunal list for the Kilmaluag Formation, Scotland. 


\begin{tabular}{|c|c|c|c|}
\hline Chondrichthyes & Hybodontiformes & & $\begin{array}{l}\text { Acrodus caledonicus } \\
\text { Hybodus sp. } \\
\text { Hybodont indet. }\end{array}$ \\
\hline \multirow[t]{3}{*}{ Osteichthyes } & Amiiformes & & Amiiformes indet. \\
\hline & Pycnodontiformes & & Pycnodontiformes indet. \\
\hline & Semionotiformes & & Lepidotes \\
\hline Sarcopterygii & Coelacanthiformes & & ?coelacanth \\
\hline \multirow[t]{2}{*}{ Lissamphibia } & & Albanerpetontidae & cf.Anoualerpeton sp. \\
\hline & & Caudata & $\begin{array}{l}\text { Marmorerpeton kermacki } \\
\text { 'Kirtlington Salamander A' }\end{array}$ \\
\hline \multirow[t]{14}{*}{ Sauropsida } & Testudinata & & $\begin{array}{l}\text { Eileanchelys waldmani } \\
\text { Chelonia indet. }\end{array}$ \\
\hline & Lepidosauromorpha & $\begin{array}{l}\text { Lepidosauromorph } \\
\text { a indet }\end{array}$ & $\begin{array}{l}\text { Marmoretta sp. } \\
\text { Taxon A } \\
\text { Taxon B } \\
\end{array}$ \\
\hline & & Squamata indet & $\begin{array}{l}\text { Parviraptor sp. } \\
\text { Taxon nov. A } \\
\text { Taxon nov. B } \\
\text { Bellairsia sp. } \\
\end{array}$ \\
\hline & & ?Paramacellodidae & $\begin{array}{l}\text { Balnealacerta } s p . \\
\text { ? Paramacellodid indet }\end{array}$ \\
\hline & & Incertae sedis & Taxon nov. \\
\hline & Choristodera & 8 & $\begin{array}{l}\text { Cteniogenys sp. } \\
\text { Choristodera indet. }\end{array}$ \\
\hline & Archosauromorpha & Crocodylomorpha & $\begin{array}{l}\text { Goniopholidae indet. } \\
\text { Atoposauridae indet. } \\
\text { Unnamed Crocodylomorpha } \\
\text { Goniopholidae indet. }\end{array}$ \\
\hline & & Dinosauria indet. & Dinosauria indet. \\
\hline & & Sauropoda & Neosauropoda indet. (not Cetiosaurus) \\
\hline & & & Sauropoda indet. \\
\hline & & Theropoda & Theropoda indet. \\
\hline & & Pterosauria & $\begin{array}{l}\text { Rhamphorhynchoidea indet. } \\
\text { Pterodactyloidea indet. }\end{array}$ \\
\hline & & Reptilia indet. & Reptilia A \\
\hline & & & $\begin{array}{l}\text { Reptilia B } \\
\text { Reptilia C }\end{array}$ \\
\hline \multirow[t]{6}{*}{ Synapsida } & Mammaliamorpha & & Stereognathus ooliticus \\
\hline & \multirow[t]{2}{*}{ Mammaliaformes } & Morganucodonta & Wareolestes rex \\
\hline & & Docodonta & $\begin{array}{l}\text { Borealestes serendipitus } \\
\text { Borealestes sp. nov. } \\
\text { Krusatodon kirtlingtonensis } \\
\text { Krusatodon sp. }\end{array}$ \\
\hline & \multirow[t]{2}{*}{ Mammalia } & Cladotheria & Palaeoxonodon ooliticus \\
\hline & & Eutriconodonta & Phascolotherium sp. \\
\hline & Incertae sedis & & Mammalia indet. \\
\hline
\end{tabular}

Table 1: Updated vertebrate faunal list for the Kilmaluag Formation, Scotland. 
A

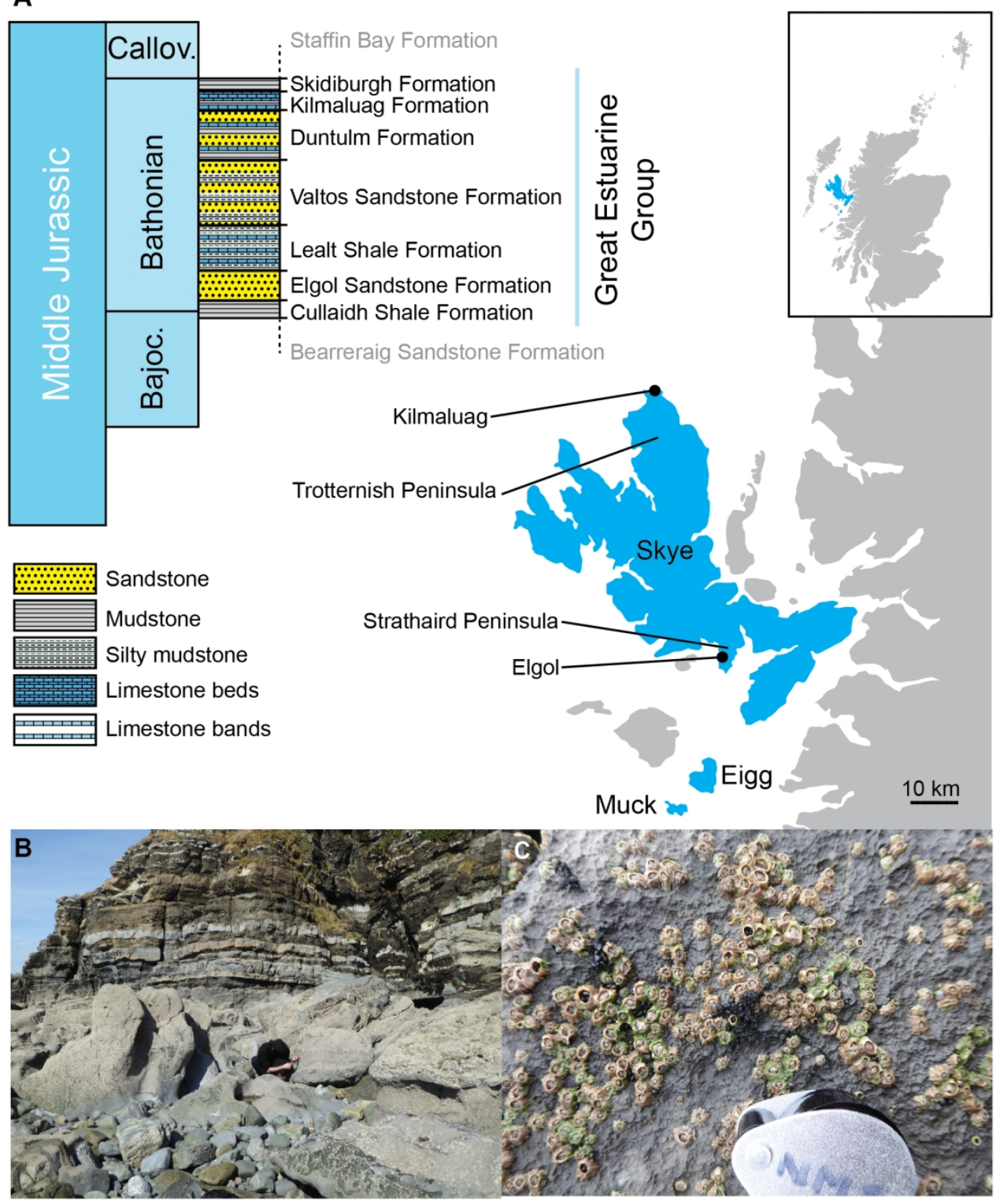

Figure 1. The location of surface outcrops of the Kilmaluag Formation, and overview of the stratigraphy of the Great Estuarine Group (A). Outcrops north of Elgol (B), and the appearance of bone (black) against the micritic blue-grey limestone (C). Map adapted from Wikimedia Commons. Stratigraphy compiled and adapted from Cohen et al. 2018, Andrews, 1985, and Barron et al. 2012). 


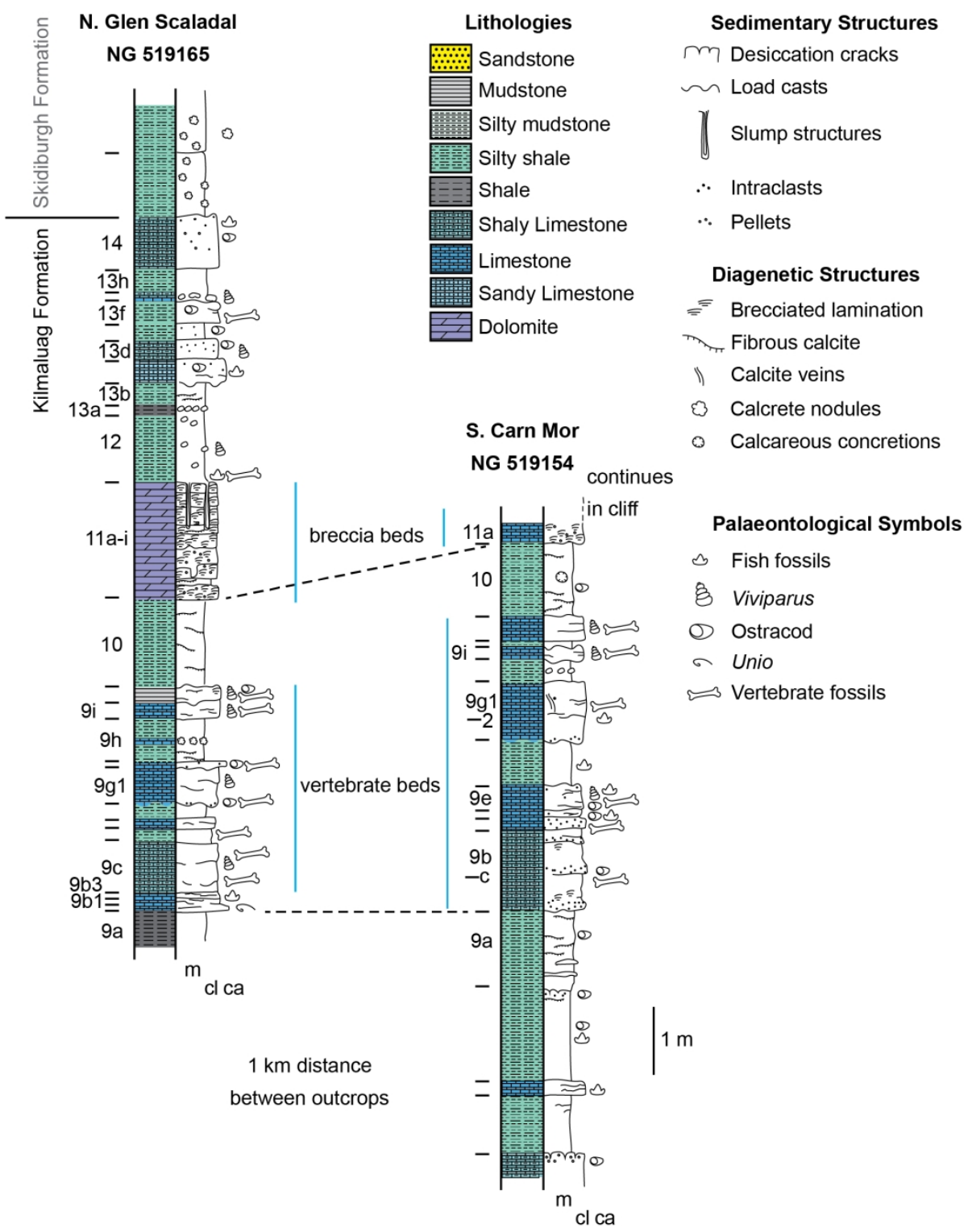

Figure 2. Stratigraphy of the Kilmaluag Formation at two main fossil collection sites on the Strathaird Peninsula. Adapted from Andrews, 1985. 


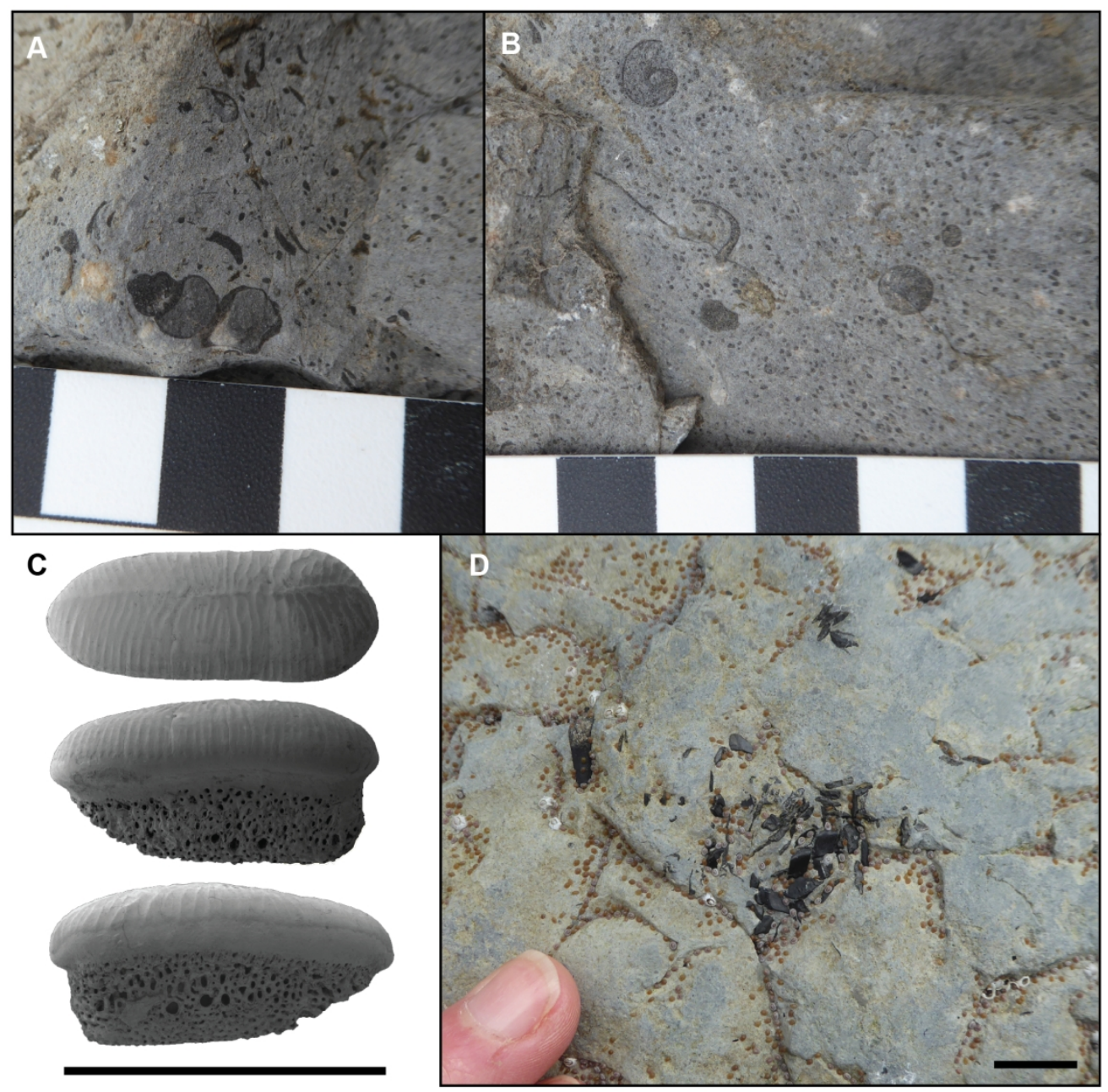

Figure 3. Invertebrate fossils in the Kilmaluag Formation: Viviparus (A); ostracods (B); hybodont shark Acrodus caledonicus NHM P.6642 (C) (adapted from Rees \& Underwood [2005; fig 5]); and an identified fish fossil in situ (D). Scale bars for (C) and $(D)=10 \mathrm{~mm}$. 

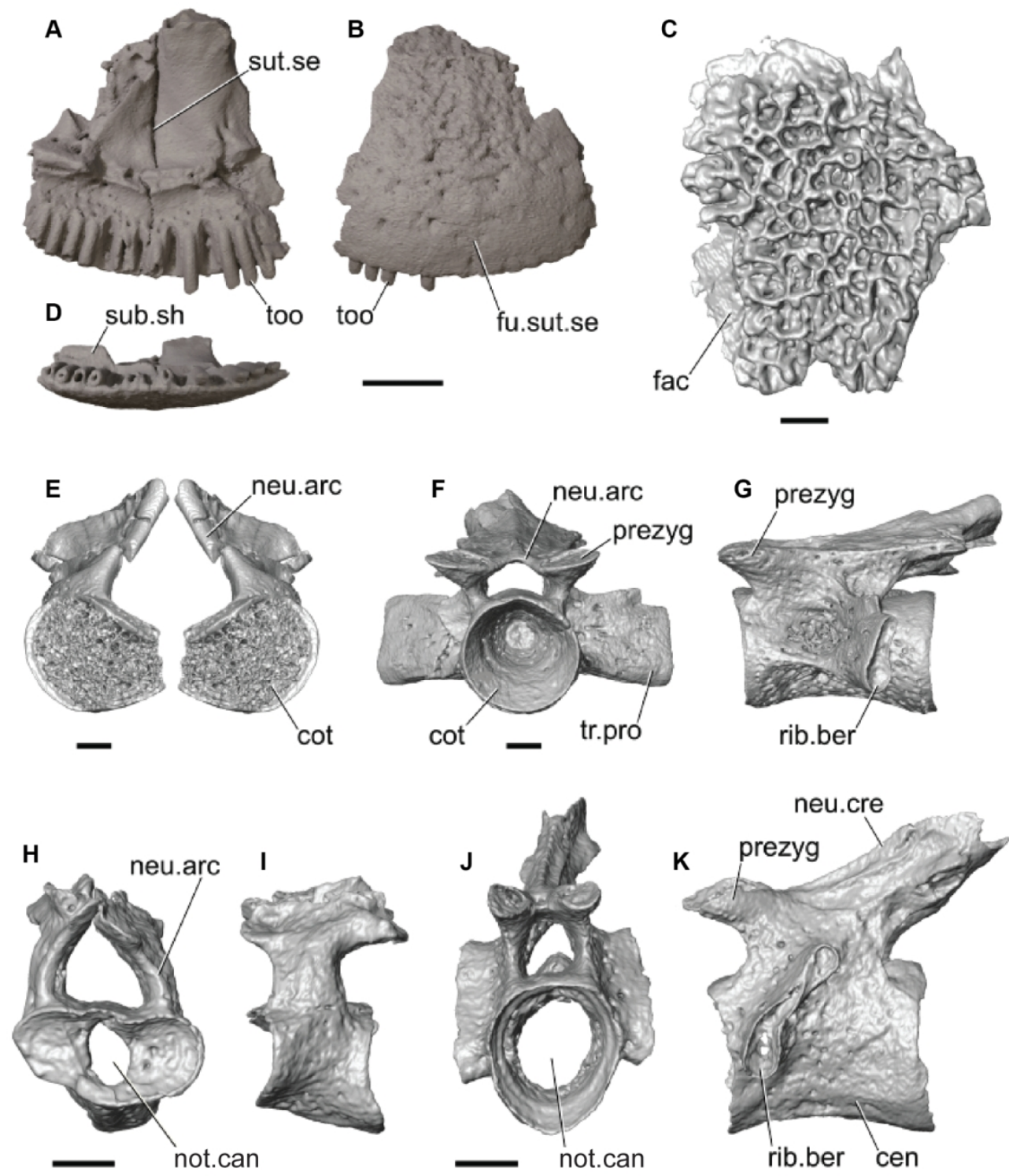

Figure 4. Amphibians. Premaxillae of Albanerpetontidae cf. Anoulerpeton priscus NMS G.2019.34.6 in lingual (A), labial (B), and occlusal view (C). Marmorerpeton roofing bone (field number ELGOL.2019.15) in dorsal view (D). Partial atlas of Marmorerpeton (ELGOL.2016.019) in rostral view with left right side reflected to represent the right side (D). Dorsal vertebra of Marmorerpeton (ELGOL.2016.024) in rostral view (F) and left lateral view (G). Atlas of 'Salamander A' (field number ELGOL.2016.004) in rostral view (H) and left lateral view (I). Dorsal vertebra of 'Salamander A' (field number ELGOL.2016.004) shown in anterior (J) and left lateral view (K). Abbreviations: brk=breakage; cen=centrum; $D E N=$ dentary; fac=facet; fac. pro=facial process; for=foramen; fu.sut.se= fused suture seam; lin.sh= lingual shelf; MAX=maxilla;

Mck.gro=Meckelian groove; muc.sca=muscle scar; nar=naris; neu.arc=neural arch; not. $\operatorname{can=notochordal~}$ canal; neu.cre=neural crest; pmx.fact=premaxilla facet; prezyg=presygapophyses; PRF=prefrontal; res. pit=resorption pit; rib.ber=rib bearer; spl.fac=splenial facet; sub.sh=subdental shelf; sym=symphysis; too=tooth; tr.pro=transverse process. All scale bars $=1 \mathrm{~mm}$. 

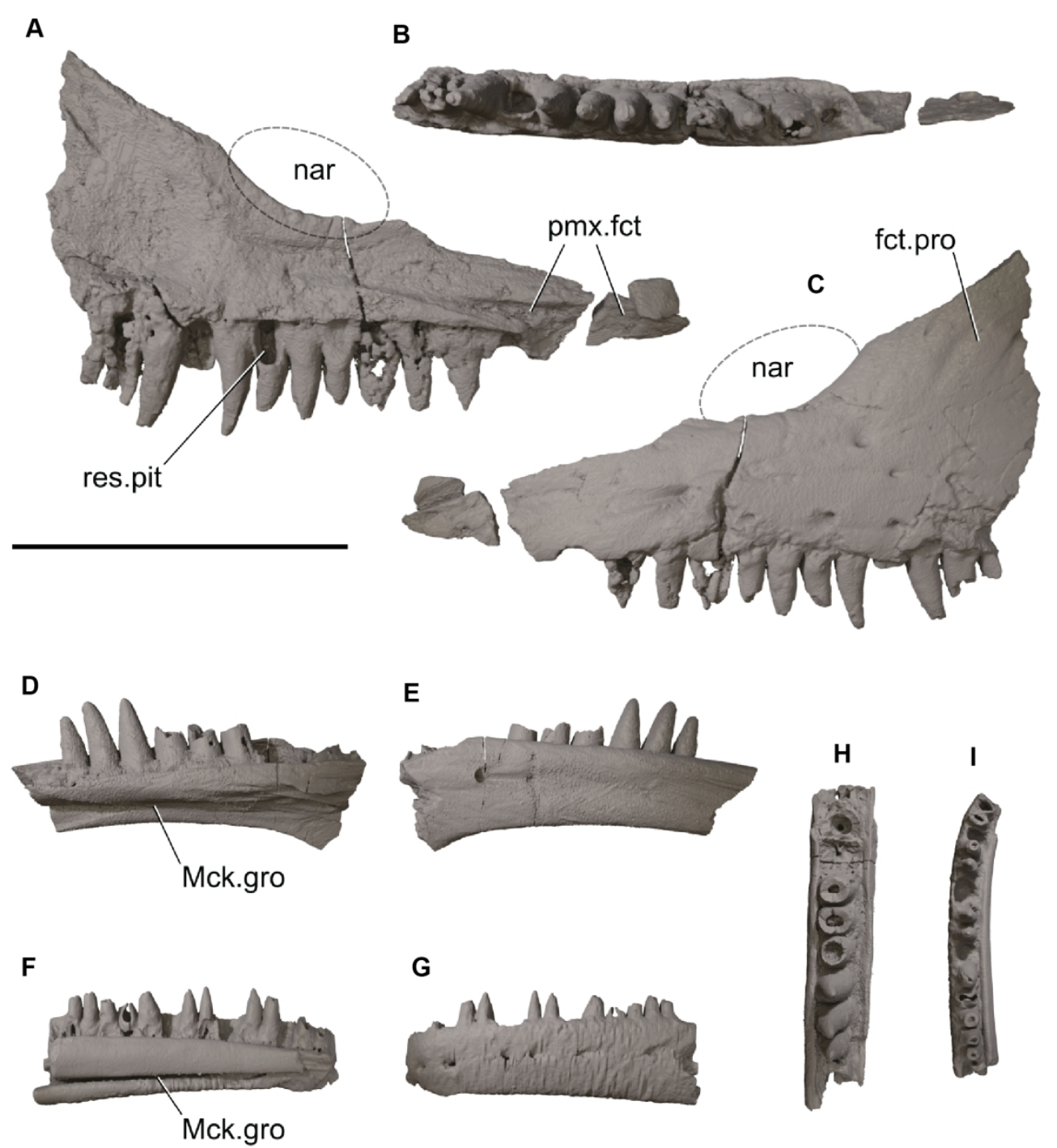

Figure 5. Lepidosauromorphs from the Kilmaluag Formation: Marmoretta NMS G.1992.47.4 in lingual (A), apical (B) and labial (C) view; Lepidosauromorph 'species A' NMS G.2019.34.9 in lingual (D), labial (E) and apical (H) views; and Lepidosauromorph 'species B' NMS G.2019.34.13 in lingual (F), labial (G) and apical (I) views. Abbreviations as for Fig. 4 . Scale bar $=5 \mathrm{~mm}$. 
A

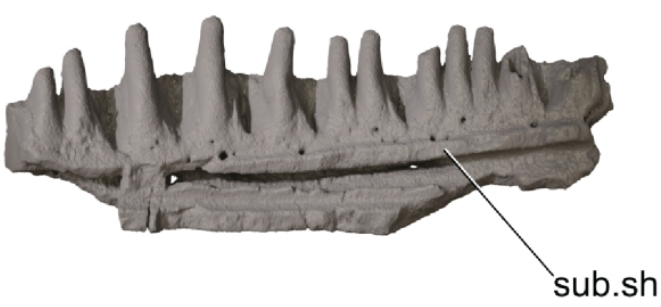

B

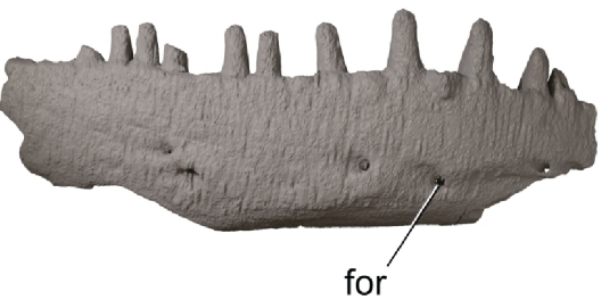

C

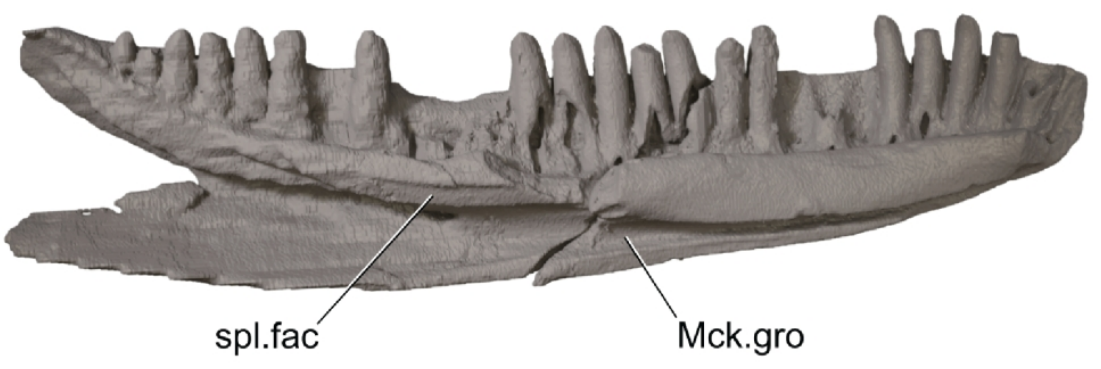

D

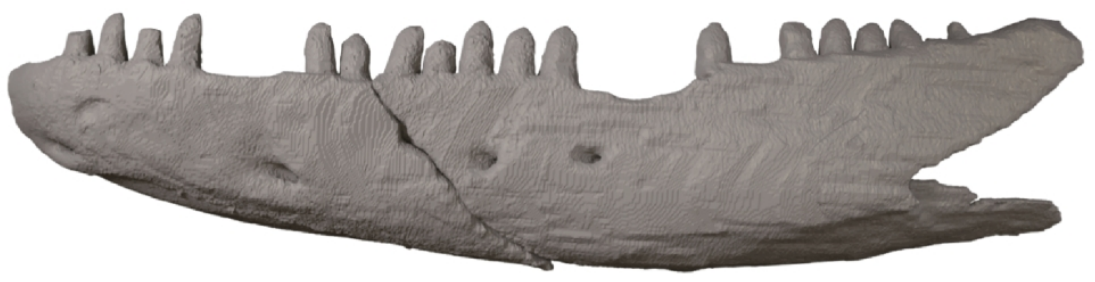

E

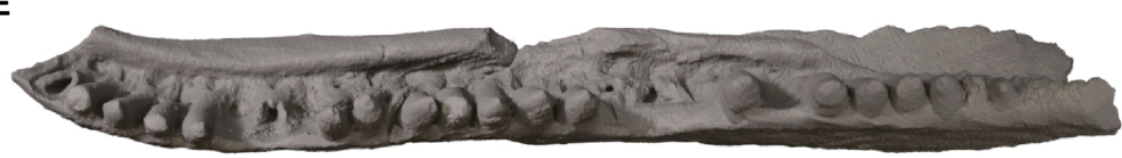

Figure 6. Squamates: tricuspid squamate dentary, NMS G.1992.47.125 in lingual (A) and labial (B) views; squamata cf. Paramacellodidae NMS G.2019.34.11 in lingual (C) labial (D) and apical view (E). Abbreviations as for Fig. 4. Scale bar $=5 \mathrm{~mm}$. 

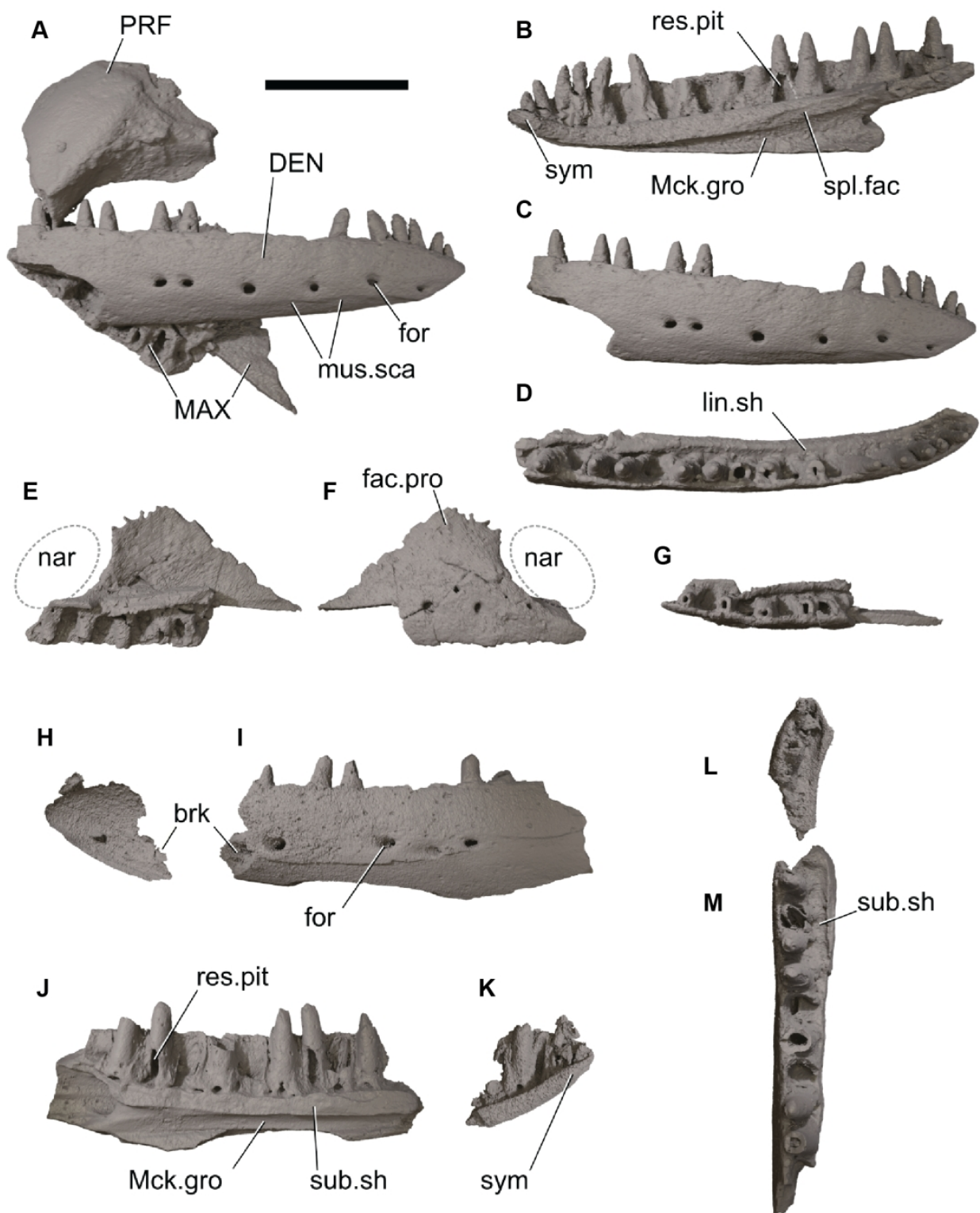

Figure 7.Squamates from the Kilmaluag Formation: Balnealacerta silvestris NMS G.2019.34.3 dentary and partial maxilla (A), with the dentary in lingual (B), labial (C), and apical (D) views, and maxilla in lingual (E), labial (F), and apical (G) views; Bellairsia gracilis. NMS G.2019.34.1 in labial (H and I), lingual (J and K), and apical ( $L$ and $M$ ) views. Abbreviations as for Fig. 4. Scale bar $=5 \mathrm{~mm}$. 

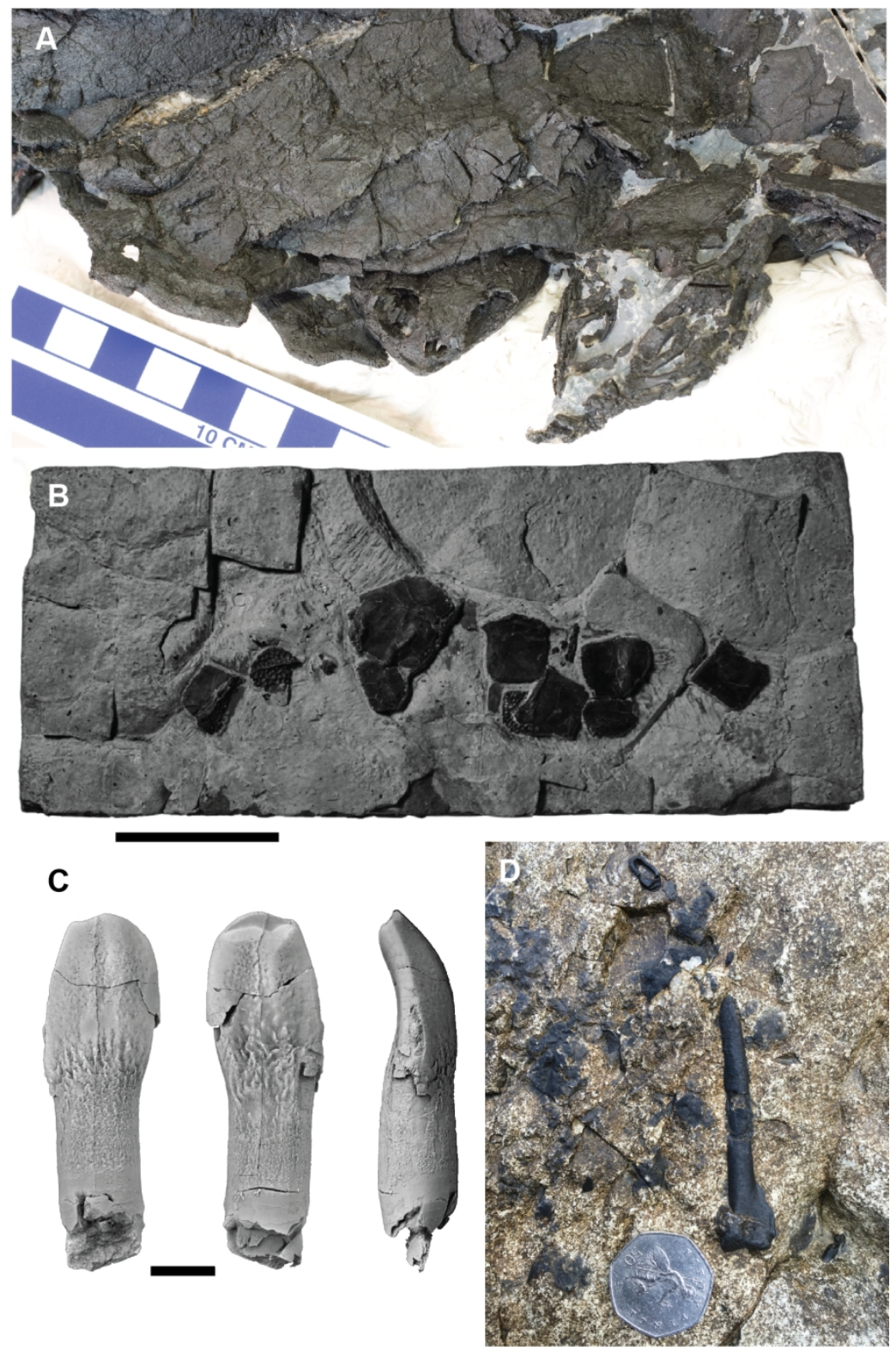

Figure 8. Reptile fossils from the Kilmaluag Formation: turtle Eileanchelys waldmani NMS G.2004.31.16d (A) (image: A. Anquetin); crocodylomorph osteoderms NHMUK R36713 (B) (adapted from Wills et al. [2014; fig 4a]); sauropod dinosaur tooth NMS G.2004.31.1 (C) (adapted from Barrett [2006: fig 1]); and a nonpterodactyloid pterosaur collected in 2016 (D) (Photo by R Close). Scale bars: B $=50 \mathrm{~mm}$, for C $=5 \mathrm{~mm}$. 
A

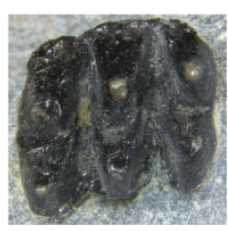

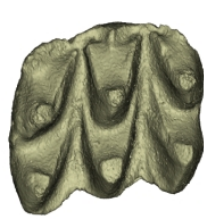

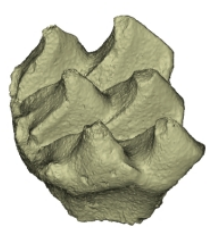

B
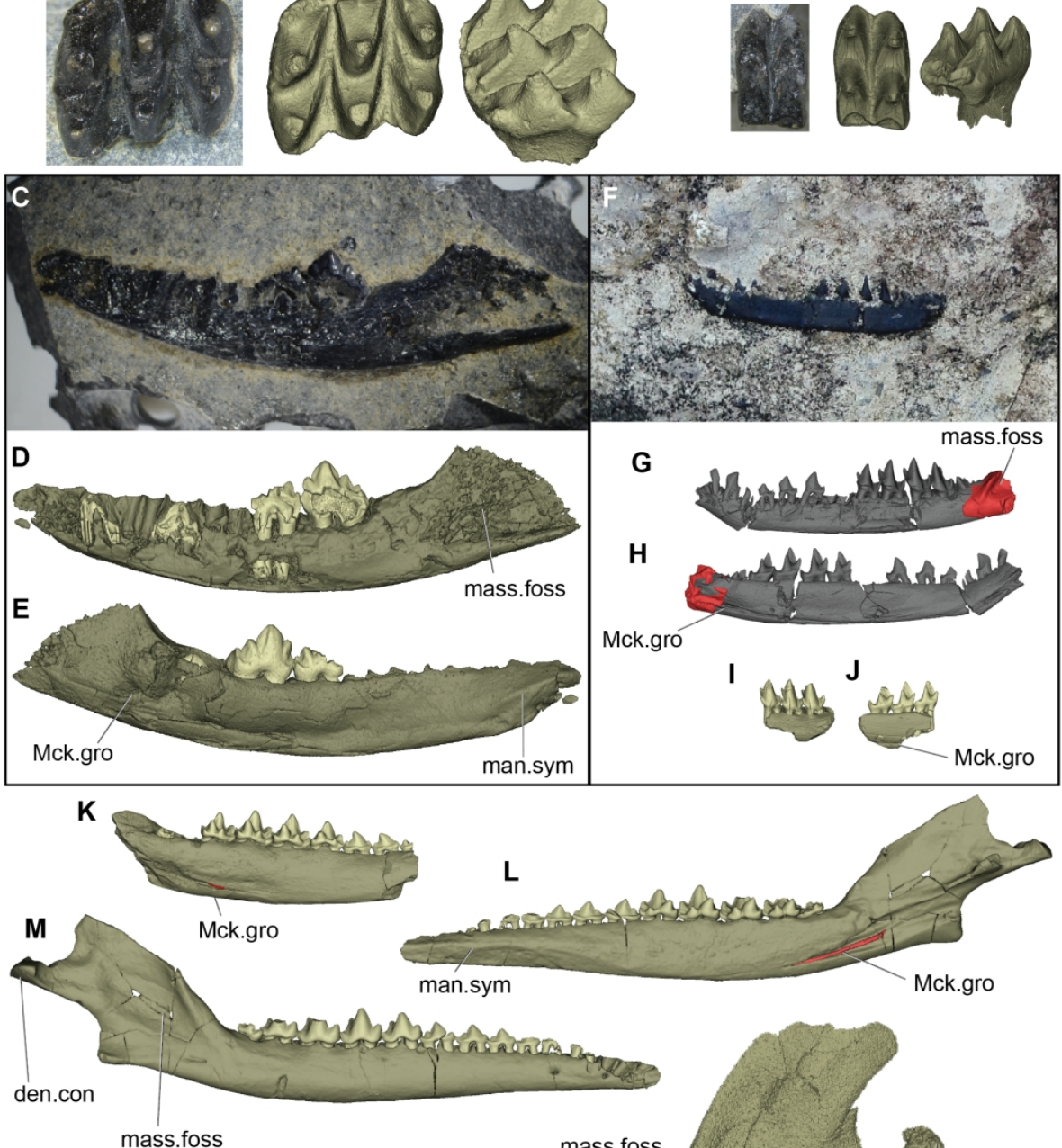

mass.foss

mass.foss

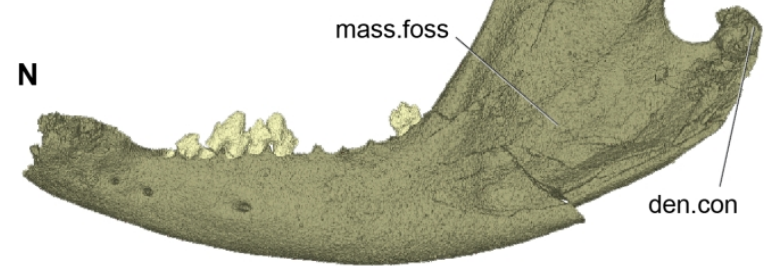

Figure 9. Mammaliamorphs from the Kilmaluag Formation: Stereognathus ooliticus NMS G.2017.17.2 (A), and NMS G.1992.47.120 (B) (adapted from Panciroli et al. [2017;5 and 7]); Wareolestes rex NMS G.2016.34.1, photographed in matrix (C), digitally segmented in labial view (D) and lingual view (E) (adapted from Panciroli et al. [2017; fig 2 and 3]); Palaeoxonodon ooliticus NMS G.2016.17.1 in the field (F) (image: R. Close), and combined with NMS G.2017.37.1 (red) in labial (G) and lingual view (H);

Palaeoxonodon ooliticus NMS G.1992.47.123 in labial (I) and lingual view (J) (adapted from Panciroli et al. [2017; figs 1 and 3]); Borealestes serendipitus BRSUG 20570 holotype (K), Borealestes serendipitus NMS G.1992.47.121.3 in lingual (L) and labial view (M); Phascolotherium sp. (field number ELGOL2017.023) in labial view (N). Abbreviations: dent.cond=dentary condyle; mass.foss=masseteric fossa;

man.sym=mandibular symphysis; Mck.gro=Meckelian groove. Scale bar $=5 \mathrm{~mm}$, same scale throughout. 


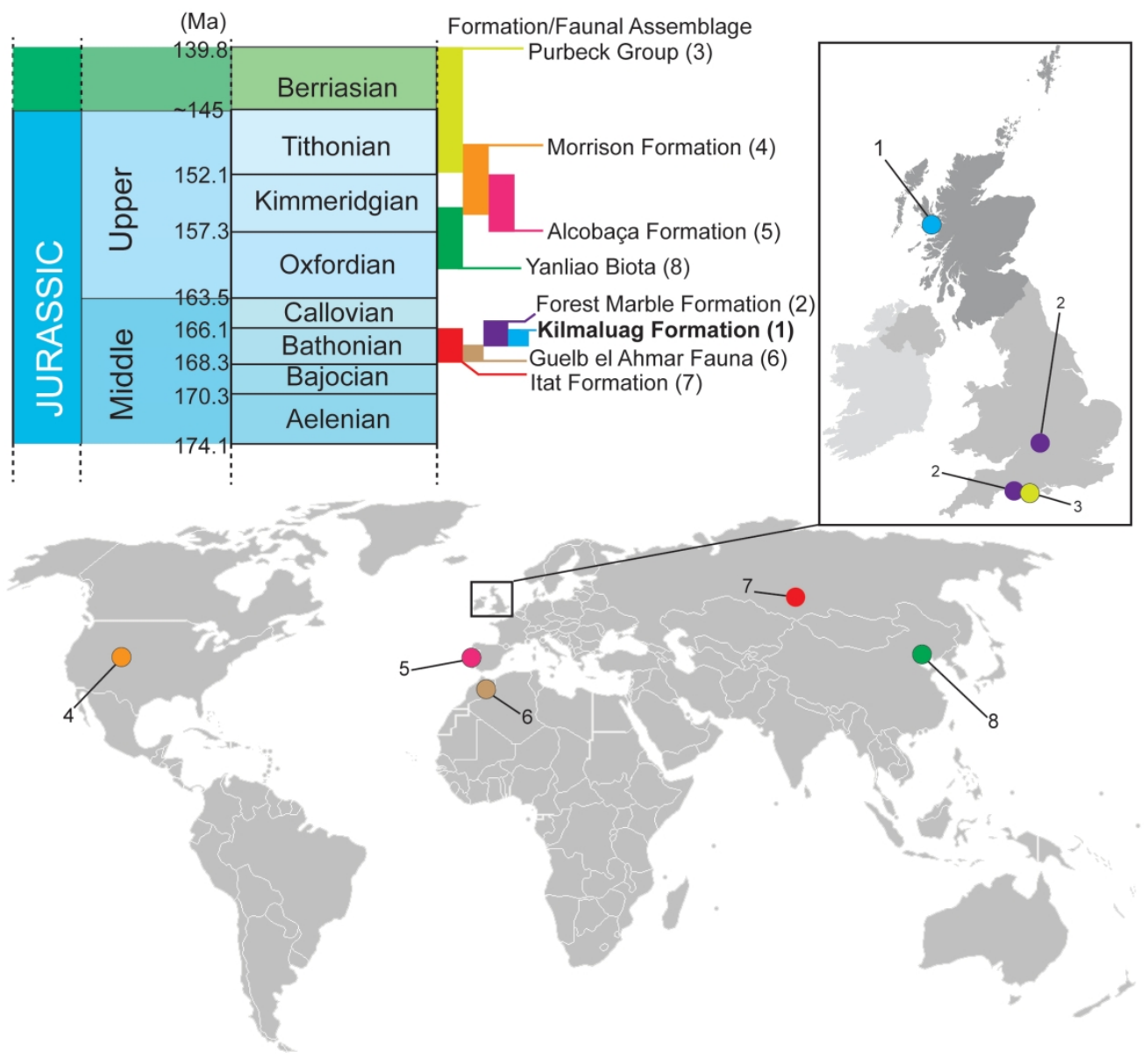

Figure 10. Location and age of the Jurassic and Cretaceous vertebrate assemblages discussed.

$747 \times 687 \mathrm{~mm}(72 \times 72 \mathrm{DPI})$ 

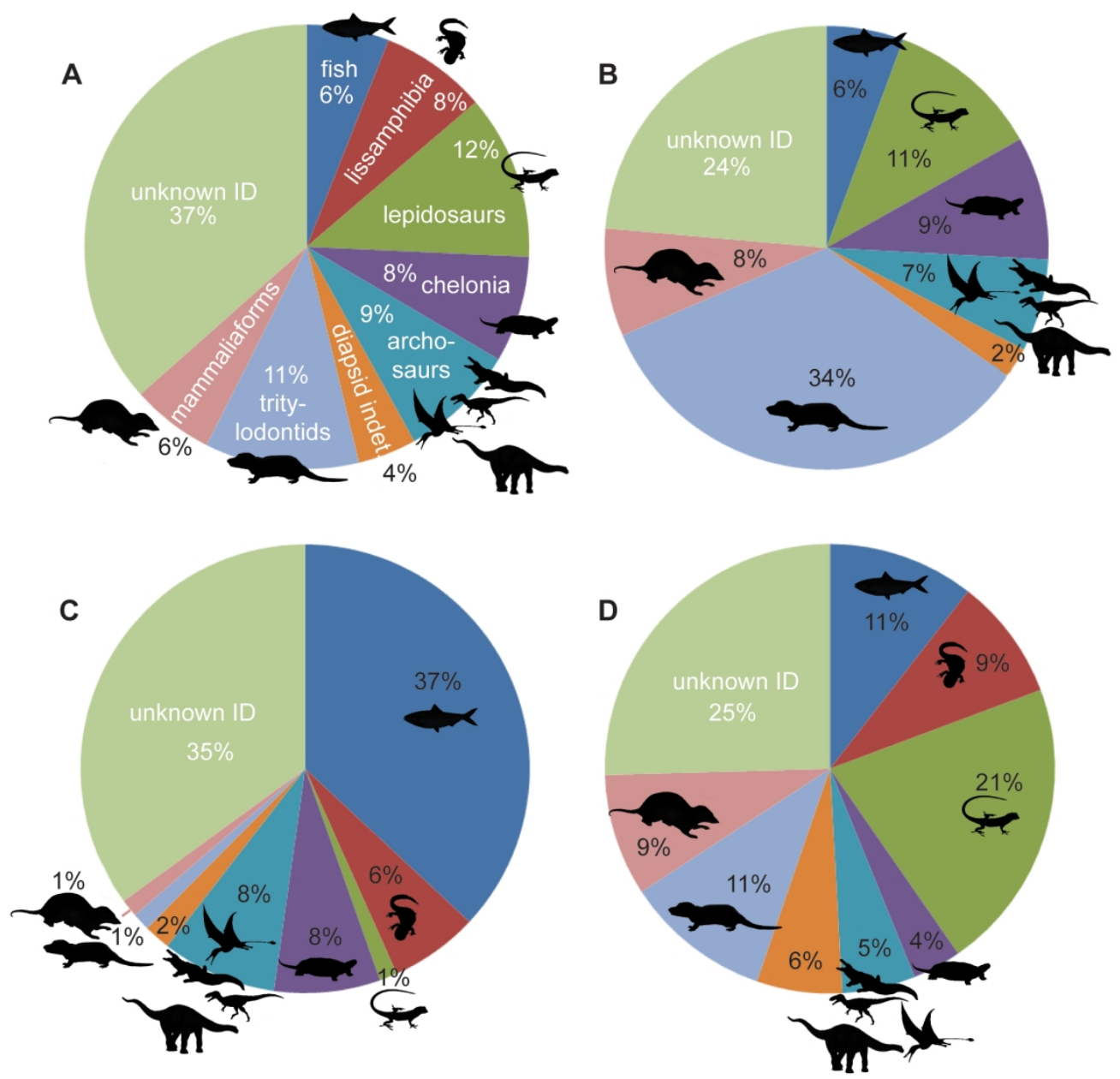

Figure 11. Proportion of each vertebrate group collected by research teams from the Kilmaluag Formation: since the sites discovery in 1971 (A); in the 1970-80s by Dr Michael Waldman and Prof Robert Savage (B); in the early 2000s by Prof Susan Evans and Prof Paul Barrett (C); and since 2010 by the universities of Oxford, Birmingham, and National Museums Scotland (D). Silhouettes created by EP.

$682 \times 655 \mathrm{~mm}(72 \times 72 \mathrm{DPI})$ 